\title{
Microbiological Factors of Food Quality for Risk Assessments in Europe: A Systematic Review
}

\author{
Maria-Eleni Dimitrakopoulou \\ Department of Public Health, Medical School, University of Patras, Patras, Greece \\ Email: dimitrakopoulou@upatras.gr \\ Apostolos Vantarakis* \\ Department of Public Health, Medical School, University of Patras, Patras, Greece \\ *Correspondence: avanta@upatras.gr
}

\begin{abstract}
Public authorities and consumers worldwide are increasingly concern about food quality and safety. Europe has established and suggested management systems in food industry that control hazards in food products. However, outbreak incidents by foodborne pathogens existing until now. European studies that present microbiological risk factors or studies which have conducted microbiological risk assessments about a variety of food products, which represent increased risk of harboring pathogens, are included. By using PRISMA guideline, we searched for the most recent publications from 2017-2021 referring microbiological risk assessments from online databases Scopus, PubMed and Science Direct. From 505 articles initially captured, data was extracted from 84 studies regarding microbiological risk factors in terms of food quality and safety, that are evidenced in European studies. Moreover, information about country of origin, food type, production phase and technology used for detection of pathogens, are also presented. Our results, indicate that quality systems should be further developed in order to control all possible routes of contamination in the supply chain. This work provides information to managers in food industry and scientists for further research regarding microbiological risk assessments.
\end{abstract}

Keywords: microbiological risk assessment, risk factors, food quality, food safety, foodborne pathogens

DOI: $10.7176 / \mathrm{FSQM} / 113-03$

Publication date: February $28^{\text {th }} 2022$

\section{Introduction}

Food quality can be described as a plethora of essential requirements, which are targeted at "consumer's satisfaction" (Peri, 2006). Consumers requirements for food quality, include food safety, nutritional needs, appearance and sensory attributes, packaging, food traceability, availability, price etc.(Savelli et al., 2019). Since food safety has become mandatory for food quality, public authorities are insisting that comprehensive quality management systems should be developed and utilized in food industry (Panghal et al., 2018).

A main challenge of food safety includes microbiological safety (Fung et al., 2018). Numerous pathogens are transmitted via food and according to a recent survey, there are millions of incidents recorded in Europe in the last decade (Sarno et al., 2021). More specific, foodborne pathogens such as bacteria, fungi, parasites and viruses can be detected in different stages of production or distribution of a food product (Martinović et al., 2016). Listeria monocytogenes, Salmonella spp., Vibrio spp., Campylobacter spp., E. coli, and adenovirus are well-known pathogens responsible for foodborne illnesses in all regions of the world. Examples of predominant symptoms caused by these foodborne pathogens are nausea, vomiting, diarrhea, cramps, fever, headache, cough etc. (Bintsis, 2017). Therefore, it is essential need to detect, manage and prevent of foodborne pathogens "from farm to fork" regarding consumers health risks (Alegbeleye et al., 2018).

According to FAO, risk analysis is proposed as suitable tool for quality management systems in food industry (FAO, 2020). By monitoring food control procedures efficiently and facing up foodborne pathogens in terms of food safety and quality, risk analysis approaches are essential for consumers protection (Suhendra et al., 2020). Nowadays, Good Manufacturing Practices (GMP) and Hazard Analysis and Critical Control Point (HACCP) are utilized in the majority of sectors involved in food industry. Additionally, quality systems include risk analysis, which target to the entire food supply chain and therefore, address issues related to microbiological hazards (Ramos et al., 2021).

Microbiological Risk Assessment, Risk Management and Risk Communication considered to be the sections which constitute a risk analysis (European Parliament and Council, 2018). In terms of a Microbiological Risk Assessment, the most important step is to identify risk factors, which are responsible for the occurrence of foodborne pathogens (FAO/WHO, 2021). Importantly, by a microbiological risk assessment, a better understanding of the behavior of microorganisms in the food matrix, while evaluation of procedures and hygiene conditions in supply chain can be achieved (den Besten et al., 2018). Hence, the last decade, omics- technologies have been widely recruited, in order to obtain information about the ecology and physiology of microorganisms (Rantsiou et al., 2018). Metagenomics, metatranscriptomics, metaproteomics and meta-metabolomics 
approaches have been adapted in microbiological risk assessments and have been demonstrated as key solution for food safety concerns (Cocolin et al., 2018).

The aim of this systematic review is to identify risk factors related to food quality and safety issues, in correlation to foodborne pathogens, food type and production phase. This work will also provide to managers in food industry and scientists an overview of current publications regarding microbiological risk factors and technology used for pathogens detection, with an insight on gaps identified.

\section{Materials and Methods}

\subsection{Protocols}

The present systematic review has been conducted, based on PRISMA guidelines: Literature search, Study selection and Analysis process.

\subsection{Eligibility Criteria}

All microbiological risk assessments were included in the first step, respective of their publication date. The literature search was conducted with no language or publication status restrictions except the condition that an abstract in English existed, referring the information of interest. The inclusion and exclusion criteria were set as follows:

\section{Inclusion criteria:}

- Studies conducted in Europe

- $\quad$ Studies about foodstuff

- Foodborne pathogens

- At least one of the following information is referred: microbiological risk assessment, microbiological risk factor

Exclusion criteria:

- No factors reported

- $\quad$ Studies about drugs/medicine/water type

- $\quad$ Non-EU-based study and outbreaks

\subsection{Information Sources and Literature search}

All empirical studies were identified by systematical searching of the following electronic databases: Science Direct (Elsevier), Scopus (Elsevier) and PubMed (NCBI). Studies published over the past 4 years i.e. 2017 onwards were included in this comprehensive literature review by using these three online databases. The study was performed in September 2021. We used the following search terms (adapted for each database): (Microbiological) AND (Risk assessment) AND (Food safety) AND (Food quality) AND (foodborne pathogens). For the comprehensive literature search, the search strings used are as follow: TITLE-ABS-KEY (microbiological AND risk AND assessment AND food AND quality AND foodborne AND pathogens AND food AND safety) AND (LIMIT-TO (PUBYEAR, 2020) OR LIMIT-TO (PUBYEAR, 2019) OR LIMIT-TO (PUBYEAR, 2018) OR LIMIT-TO (PUBYEAR, 2017))

\subsection{Study selection}

Two reviewers (MD and AV) assessed all records for inclusion basically upon the article title and the abstract provided. Mendeley was used to identify duplicated articles. For all publications included, the two reviewers (MD and AV) extracted data separately using standardized data extraction form. All abstracts that did not meet our criteria were excluded, while the remaining articles and those whose abstracts did not clearly provide proper information, were further assessed via their full-text evaluation. The authors reviewed the potentially relevant studies according to the eligibility criteria to define which studies would finally be selected for this systematic review.

\subsection{Data collection process and items}

Two authors (MD and AV) independently analyzed and extracted the following data: first author name, country of risk assessment conducted, food type involved, production phase of food product examined, foodborne pathogen detected, technology used in the article and finally risk factors reported.

\section{Results}

\subsection{Study selection}

Only original research papers published with an abstract in English were included. Initially, a total of 505 articles were identified. Afterwards, the number of publications was reduced to 498 by removing duplicates. The following stage involved the elimination of articles in which titles and abstracts either did not refer to microbiological risk assessments or did not constitute a part of it. After assessing the full text of the remaining 
papers $(n=290)$ in terms of food quality and safety, relevant research papers were identified. From those, 206 papers were discarded since they were non-Europe studies or there was not reported a case study of microbiological risk assessment. Papers in the final set $(n=84)$ mainly concerned microbiological risk assessments in Europe. The systematic literature Review approaches are depicted in Fig. 1.

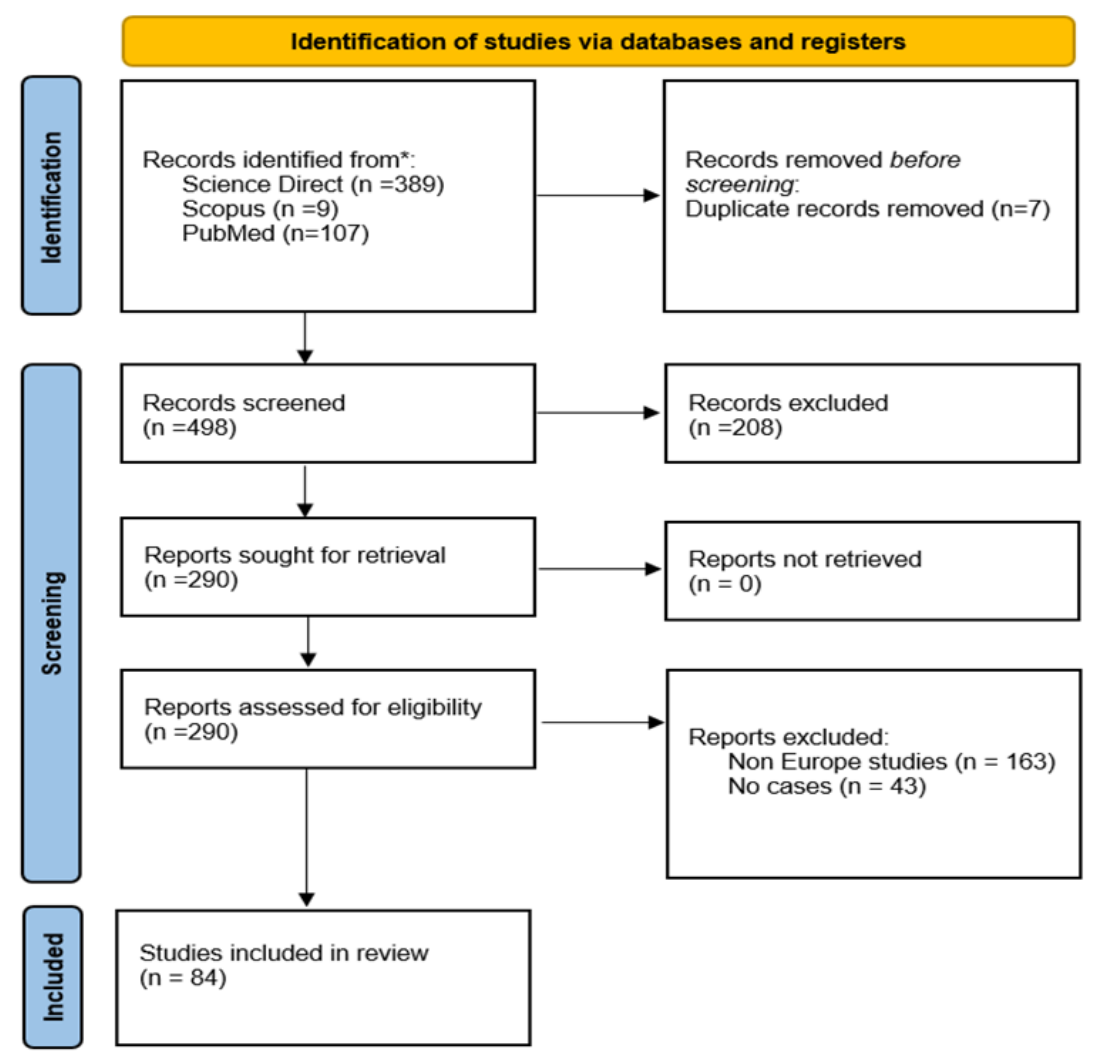

Figure 1. Prisma flow diagram

\subsection{Study characteristics}

Details of the included studies are presented in Table 1. using the following parameters: first name of author, food product, production phase, foodborne pathogen, country, risk factor and technology used.

Table 1. Characteristics of all articles included in this work (matrix, production phase, foodborne pathogen, country, risk factor, technology)

\begin{tabular}{|c|c|c|c|c|c|c|}
\hline & Matrix & $\begin{array}{l}\text { Production } \\
\text { Phase }\end{array}$ & Pathogen & Country & Risk Factor & Technology \\
\hline (Loukiadis et al., 2017) & Beef & Grinding & E.coli & France & Sampling process & Microbial cultures \\
\hline $\begin{array}{l}\text { (Fernandez-Cassi et al., } \\
\text { 2017) }\end{array}$ & Parsley & Production & Virus & Spain & Irrigation & $\begin{array}{c}\text { Next Generation Sequencing } \\
\text { (NGS) }\end{array}$ \\
\hline (Bolívar et al., 2018) & $\begin{array}{l}\text { Seabream/ } \\
\text { Seabass }\end{array}$ & Retail market & $\begin{array}{c}\text { Listeria } \\
\text { monocytogenes }\end{array}$ & Spain & Storage conditions & Microbial cultures \\
\hline $\begin{array}{l}\text { (Pérez-Rodríguez et al., } \\
\text { 2019) }\end{array}$ & Lettuce & Process & Norovirus & Spain & Food handling practices & Not mentioned \\
\hline (Duqué et al., 2021) & Poultry & $\begin{array}{c}\text { Slaughter } \\
\text { process }\end{array}$ & $\begin{array}{c}\text { Campylobacter } \\
\text { jejuni }\end{array}$ & France & Storage conditions & Microbial cultures \\
\hline (Mataragas et al., 2018) & Cheese & Manufacture & $\begin{array}{l}\text { Lactobacillus } \\
\text { spp. }\end{array}$ & Greece & Ripening & $\begin{array}{c}\text { Next Generation Sequencing } \\
\text { (NGS) }\end{array}$ \\
\hline (Filipello et al., 2020) & Dairy & Distribution & $\begin{array}{c}\text { Listeria } \\
\text { monocytogenes }\end{array}$ & Italy & Reservoir level & $\begin{array}{l}\text { Whole genome sequencing } \\
\text { (WGS) }\end{array}$ \\
\hline (Guillén et al., 2020) & N.M & Supply chain & Salmonella spp. & Spain & Preservation & Microbial cultures \\
\hline (Zampieri et al., 2020) & Mollusk & Depuration & Vibrio spp. & Italy & $\begin{array}{l}\text { Ozone treatments and } \\
\text { density }\end{array}$ & $\begin{array}{c}\text { Microbial cultures/ } \\
\text { Next Generation Sequencing } \\
\text { (NGS) }\end{array}$ \\
\hline (Lüth et al., 2020) & Meat & Production & $\begin{array}{c}\text { Listeria } \\
\text { monocytogenes }\end{array}$ & Germany & $\begin{array}{l}\text { Niches in the production } \\
\text { line }\end{array}$ & $\begin{array}{l}\text { Whole genome sequencing } \\
\text { (WGS) }\end{array}$ \\
\hline $\begin{array}{l}\text { (Merget, B., Forbes, K. } \\
\text { J., Brennan, F., McAteer, } \\
\text { S., Shepherd, } \\
\text { Strachan, N. J., \& } \\
\text { Holden, 2019) }\end{array}$ & $\begin{array}{l}\text { Seeds/Veg } \\
\text { etables }\end{array}$ & Production & E.coli & UK & $\begin{array}{c}\text { plant species, tissue type, } \\
\text { Temperature }\end{array}$ & Microbial cultures \\
\hline
\end{tabular}




\begin{tabular}{|c|c|c|c|c|c|c|}
\hline & Matrix & $\begin{array}{l}\text { Production } \\
\text { Phase }\end{array}$ & Pathogen & Country & Risk Factor & Technology \\
\hline (Merget et al., 2020) & $\begin{array}{c}\text { Seeds/Veg } \\
\text { etables }\end{array}$ & Production & E.coli & UK & metabolic flexibility & Microbial cultures \\
\hline (Rahman et al., 2017) & Mollusk & Breeding & Vibrio spp. & Italy & Temperature & $\begin{array}{l}\text { Multi-locus Sequence Analysis } \\
\text { (MLSA) }\end{array}$ \\
\hline (Lytou et al., 2020) & $\begin{array}{c}\text { Marinated } \\
\text { chicken }\end{array}$ & Retail market & $\begin{array}{c}\text { Campylobacter } \\
\text { spp., } \\
\text { Salmonella } \\
\text { spp., Listeria } \\
\text { monocytogenes }\end{array}$ & Greece & $\begin{array}{c}\text { Shelf-life/ } \\
\text { hygiene requirements }\end{array}$ & $\begin{array}{c}\text { M. cultures/multiplex } \\
\text { Polymerase Chain Reaction }\end{array}$ \\
\hline $\begin{array}{l}\text { (Díaz-Jiménez et al., } \\
\text { 2020) }\end{array}$ & $\begin{array}{c}\text { Chicken } \\
\text { and turkey } \\
\text { meat }\end{array}$ & Retail market & $\begin{array}{c}\text { Enterobacteriac } \\
\text { eae }\end{array}$ & Spain & exposition to antibiotics & $\begin{array}{c}\text { M. cultures/ Multi-locus } \\
\text { sequence typing / Whole genome } \\
\text { sequencing }\end{array}$ \\
\hline $\begin{array}{l}\text { (Gonzales-Barron et al., } \\
2020 \text { ) }\end{array}$ & Cheese & Ripening & $\begin{array}{c}\text { Listeria } \\
\text { monocytogenes }\end{array}$ & Portugal & $\begin{array}{c}\text { starter culture/ } \\
\text { environmental conditions }\end{array}$ & Microbial cultures \\
\hline (Lianou et al., 2018) & $\begin{array}{l}\text { Vanilla } \\
\text { cream } \\
\text { pudding }\end{array}$ & Manufacture & $\begin{array}{c}\text { Listeria } \\
\text { monocytogenes }\end{array}$ & Greece & storage temperature & Microbial cultures \\
\hline $\begin{array}{l}\text { (Devleesschauwer et al., } \\
\text { 2017) }\end{array}$ & Tomato & $\begin{array}{l}\text { pre-harvest } \\
\text { production }\end{array}$ & Salmonella spp. & Belgium & humidity & Microbial cultures \\
\hline (Duqué et al., 2018) & Chicken & $\begin{array}{l}\text { Slaughter } \\
\text { process }\end{array}$ & Campylobacter & France & $\begin{array}{l}\text { season effect/ } \\
\text { skin area }\end{array}$ & Microbial cultures \\
\hline $\begin{array}{ll}\text { (Ripolles-Avila et al., } \\
\text { 2019) }\end{array}$ & Fish & Packaging & S. aureus & Spain & plastic Materials & Microbial cultures \\
\hline (Jansen et al., 2019) & Cheese & $\begin{array}{l}\text { Ethnic } \\
\text { markets }\end{array}$ & Brucella spp. & Belgium & $\begin{array}{c}\text { raw milk /short ripening } \\
\text { period }\end{array}$ & $\begin{array}{c}\text { Microbial cultures/ } \\
\mathrm{qPCR} \\
\end{array}$ \\
\hline (Dinh Thanh et al., 2017) & $\begin{array}{l}\text { Paprika, } \\
\text { Pepper, } \\
\text { and } \\
\text { Oregano }\end{array}$ & Process & S. aureus & Germany & long term-storage & Microbial cultures \\
\hline $\begin{array}{l}\text { (Kapetanakou et al., } \\
\text { 2019) }\end{array}$ & $\begin{array}{c}\text { Bakery } \\
\text { products }\end{array}$ & Manufacture & Salmonella spp. & Greece & storage temperature & Microbial cultures \\
\hline $\begin{array}{l}\text { (Kapetanakou et al., } \\
\text { 2017) }\end{array}$ & Cheese & Retail market & $\begin{array}{c}\text { Listeria } \\
\text { monocytogenes }\end{array}$ & Greece & Shelf-life & Microbial cultures \\
\hline (Schill et al., 2017) & pork meat & Process & $\begin{array}{c}\text { Enterobacteriac } \\
\text { eae }\end{array}$ & Germany & $\begin{array}{c}\text { livestock, } \\
\text { farm level, environment } \\
\text { of facilities, } \\
\text { workers } \\
\end{array}$ & $\begin{array}{l}\text { Microbial cultures / } \\
\text { PCR/MLST }\end{array}$ \\
\hline (Wright \& Holden, 2018) & $\begin{array}{c}\text { Microgree } \\
n s\end{array}$ & Harvest & E.coli & UK & humidity & Microbial cultures \\
\hline (Osimani et al., 2017) & $\begin{array}{l}\text { Mealworm } \\
\mathrm{s}\end{array}$ & Retail market & $\begin{array}{l}\text { Antibiotic } \\
\text { resistance } \\
\text { strains }\end{array}$ & Italy & $\begin{array}{c}\text { rearing/ } \\
\text { antibiotics }\end{array}$ & $\begin{array}{l}\text { Microbial cultures / } \\
\text { PCR }\end{array}$ \\
\hline $\begin{array}{l}\text { (Matteo Crotta et al., } \\
\text { 2019) }\end{array}$ & Pork meat & $\begin{array}{l}\text { Slaughter } \\
\text { process }\end{array}$ & $\begin{array}{c}\text { gastrointestinal } \\
\text { pathogens }\end{array}$ & UK & $\begin{array}{l}\text { belly opening/removal of } \\
\text { gastrointestinal tract stage }\end{array}$ & Not mentioned \\
\hline (Osimani et al., 2018) & $\begin{array}{l}\text { Edible } \\
\text { insects }\end{array}$ & Retail market & Bacteria & Italy & $\begin{array}{l}\text { manufacturing practices } \\
\text { during insect process }\end{array}$ & $\begin{array}{l}\text { PCR-DGGE, metagenomics } \\
\text { sequencing, } \\
\text { qPCR }\end{array}$ \\
\hline (Cadavez et al., 2019) & Cheese & Production & $\begin{array}{c}\text { Listeria } \\
\text { monocytogenes }\end{array}$ & Portugal & $\begin{array}{c}\text { starter cultures/ } \\
\text { storage temperature }\end{array}$ & Microbial cultures \\
\hline $\begin{array}{l}\text { (Evert-Arriagada et al., } \\
2018 \text { ) }\end{array}$ & Cheese & Manufacture & $\begin{array}{c}\text { Listeria } \\
\text { monocytogenes }\end{array}$ & Spain & $\begin{array}{l}\text { High pressure processing/ } \\
\text { sanitization }\end{array}$ & Microbial cultures \\
\hline (Akineden et al., 2017) & $\begin{array}{l}\text { Powdered } \\
\text { infant } \\
\text { formula } \\
\end{array}$ & Retail market & $\begin{array}{c}\text { Cronobacter } \\
\text { spp. }\end{array}$ & Germany & Manufacturing process & $\begin{array}{l}\text { Microbial cultures / } \\
\text { PCR/MLST }\end{array}$ \\
\hline (Garre et al., 2019) & Milk & Retail market & $\begin{array}{c}\text { Listeria } \\
\text { monocytogenes }\end{array}$ & Spain & Thermal treatment & Microbial cultures \\
\hline (Alvseike et al., 2018) & Pork meat & $\begin{array}{l}\text { Slaughter } \\
\text { process }\end{array}$ & $\begin{array}{l}\text { Bacteria+Parasi } \\
\text { te }\end{array}$ & Norway & $\begin{array}{l}\text { belly opening/removal of } \\
\text { gastrointestinal tract stage }\end{array}$ & Not mentioned \\
\hline (Heir et al., 2019) & Salmon & Filleting & $\begin{array}{c}\text { Listeria } \\
\text { monocytogenes }\end{array}$ & Norway & dry-salting process & $\begin{array}{c}\text { Microbial cultures / } \\
\text { Next Generation Sequencing }\end{array}$ \\
\hline $\begin{array}{l}\text { (Papadopoulou et al., } \\
\text { 2018) }\end{array}$ & Cheese & Manufacture & $\begin{array}{c}\text { Listeria } \\
\text { monocytogenes }\end{array}$ & Greece & $\begin{array}{c}\text { starter cultures/ } \\
\text { storage temperature }\end{array}$ & Microbial cultures \\
\hline (Santarelli et al., 2018) & $\begin{array}{l}\text { leafy green } \\
\text { vegetables }\end{array}$ & Retail market & Bacteria +Virus & Italy & washing step & $\begin{array}{c}\text { Microbial cultures / } \\
\text { PCR }\end{array}$ \\
\hline (Valero et al., 2018) & Cheese & Retail market & $\begin{array}{c}\text { Listeria } \\
\text { monocytogenes }\end{array}$ & Spain & refrigeration temperature & $\begin{array}{c}\text { Microbial cultures / } \\
\text { PCR } \\
\end{array}$ \\
\hline (Imran et al., 2019) & Cheese & Retail market & $\begin{array}{c}\text { Gram-Negative } \\
\text { Bacteria } \\
\end{array}$ & France & starter cultures & Microbial cultures \\
\hline $\begin{array}{l}\text { (Rodríguez-López et al., } \\
2020 \text { ) }\end{array}$ & Fish+Meat & Process & $\begin{array}{c}\text { Listeria } \\
\text { monocytogenes }\end{array}$ & Spain & disinfection regimes & $\begin{array}{c}\text { Microbial cultures / } \\
\text { PCR } \\
\end{array}$ \\
\hline $\begin{array}{l}\text { (Juliana Lane Paixão dos } \\
\text { Santos et al., 2020) }\end{array}$ & $\begin{array}{l}\text { Strawberry } \\
\text { purees }\end{array}$ & Process & $\begin{array}{l}\text { Aspergillus } \\
\text { fischeri }\end{array}$ & Belgium & $\begin{array}{l}\text { storage temperature } \\
\text { /pasteurization }\end{array}$ & Microbial cultures \\
\hline (Xylia et al., 2019) & Salad & Retail market & Bacteria & Cyprus & $\begin{array}{c}\text { season/ } \\
\text { processing practices }\end{array}$ & $\begin{array}{c}\text { Microbial cultures / } \\
\text { PCR }\end{array}$ \\
\hline (El-Hajjaji et al., 2020a) & Milk butter & $\begin{array}{l}\text { Manufacture/ } \\
\text { Retail market }\end{array}$ & $\begin{array}{c}\text { Listeria } \\
\text { monocytogenes }\end{array}$ & Belgium & starter cultures & Microbial cultures \\
\hline (Fritsch et al., 2019) & Multiple & Multiple & $\begin{array}{c}\text { Listeria } \\
\text { monocytogenes } \\
\mathrm{s} \\
\end{array}$ & France & cold conditions & $\begin{array}{l}\text { Genome-wide Association } \\
\text { study(GWAS) }\end{array}$ \\
\hline
\end{tabular}




\begin{tabular}{|c|c|c|c|c|c|c|}
\hline & Matrix & $\begin{array}{l}\text { Production } \\
\text { Phase }\end{array}$ & Pathogen & Country & Risk Factor & Technology \\
\hline $\begin{array}{l}\text { (Bogdanovičová et al., } \\
\text { 2017) }\end{array}$ & $\begin{array}{l}\text { Milk } \\
\text { Powder }\end{array}$ & Retail market & S. aureus & $\begin{array}{c}\text { Czech } \\
\text { Republic }\end{array}$ & $\begin{array}{l}\text { storage temperature/ } \\
\text { long-term storage }\end{array}$ & Microbial cultures \\
\hline (Allende et al., 2017) & Spinach & Harvest & E.coli & Spain & $\begin{array}{c}\text { season/irrigation } \\
\text { water/weather }\end{array}$ & Microbial cultures \\
\hline (Gérard et al., 2020a) & Cheese & Manufacture & $\begin{array}{c}\text { Listeria } \\
\text { monocytogenes }\end{array}$ & Belgium & starter cultures & Microbial cultures \\
\hline (Possas et al., 2019) & Sausage & Retail market & $\begin{array}{c}\text { Listeria } \\
\text { monocytogenes }\end{array}$ & Spain & shelf-life & Microbial cultures \\
\hline (Tirloni et al., 2020) & Shrimp & Manufacture & $\begin{array}{c}\text { Listeria } \\
\text { monocytogenes }\end{array}$ & Italy & $\begin{array}{c}\text { contaminated ingredients/ } \\
\text { production practices }\end{array}$ & Microbial cultures \\
\hline (Beneduce et al., 2017) & $\begin{array}{l}\text { Tomato/ } \\
\text { Broccoli } \\
\end{array}$ & Harvest & Bacteria & Italy & irrigation & $\begin{array}{c}\text { Microbial cultures / } \\
\text { PCR } \\
\end{array}$ \\
\hline (Reich et al., 2018) & Meat & $\begin{array}{c}\text { Slaughter } \\
\text { process }\end{array}$ & Campylobacter & Germany & sampling process & Microbial cultures \\
\hline $\begin{array}{l}\text { (Correia Peres Costa et } \\
\text { al., 2020) }\end{array}$ & $\begin{array}{c}\begin{array}{l}\text { Seabream } \\
\text { /Seabass }\end{array} \\
\end{array}$ & Filleting & Bacteria & Spain & $\begin{array}{l}\text { location/ } \\
\text { shelf-life }\end{array}$ & $\begin{array}{c}\text { Microbial cultures / } \\
\text { PCR } \\
\end{array}$ \\
\hline (Li et al., 2018) & Berries & Retail market & $\begin{array}{c}\text { Hepatitis } \\
\text { A/Norovirus }\end{array}$ & Belgium & virucidal treatments & qPCR \\
\hline (Ssemanda et al., 2018) & Vegetables & Manufacture & Bacteria & $\begin{array}{c}\text { Netherland } \\
\mathrm{s}\end{array}$ & $\begin{array}{c}\text { irrigation/ } \\
\text { compost manure }\end{array}$ & $\begin{array}{c}\text { Microbial cultures / } \\
\text { PCR }\end{array}$ \\
\hline $\begin{array}{l}\text { (Márcia Oliveira et al., } \\
\text { 2019) }\end{array}$ & Berries & Manufacture & Pathogens & Portugal & $\begin{array}{c}\text { surface structure/ worker's } \\
\text { hands }\end{array}$ & $\begin{array}{l}\text { Microbial cultures / } \\
\text { PCR }\end{array}$ \\
\hline (Petruzzelli et al., 2018) & Meals & Catering & Bacteria & Italy & $\begin{array}{c}\text { washing /refrigeration } \\
\text { /temperatures/ } \\
\text { contact surface/worker's } \\
\text { hands } \\
\end{array}$ & Microbial cultures \\
\hline (Lourenco et al., 2020) & $\begin{array}{c}\text { Cheese/Mi } \\
\text { lk }\end{array}$ & $\begin{array}{l}\text { Production/ } \\
\text { Ripening }\end{array}$ & Bacteria & Ireland & surface biofilm & Microbial cultures \\
\hline $\begin{array}{lll}\text { (López-Gálvez et al., } \\
\text { 2020) }\end{array}$ & Peppers & Harvest & Bacteria & Spain & washing Line & Microbial cultures \\
\hline (Iannetti et al., 2020) & Poultry & $\begin{array}{l}\text { Slaughter } \\
\text { process }\end{array}$ & $\begin{array}{c}\text { Campylobacter/ } \\
\text { Salmonella }\end{array}$ & Italy & animal welfare/neck skin & $\begin{array}{c}\text { M. cultures/ } \\
\text { multiplex PCR }\end{array}$ \\
\hline (Garayoa et al., 2017) & $\begin{array}{l}\text { Prepared } \\
\text { foods }\end{array}$ & Catering & Bacteria & Spain & $\begin{array}{c}\text { surfaces/ } \\
\text { temperatures }\end{array}$ & Microbial cultures \\
\hline (Nastasijevic et al., 2017) & Meat & Process & $\begin{array}{c}\text { Listeria } \\
\text { monocytogenes }\end{array}$ & Serbia & $\begin{array}{c}\text { air flow/surface } \\
\text { biofilms/slaughter line }\end{array}$ & $\begin{array}{c}\text { Microbial cultures / } \\
\text { WGS }\end{array}$ \\
\hline (Rajkovic et al., 2017) & Rasberries & Manufacture & Pathogens & Serbia & $\begin{array}{c}\text { storage/water } \\
\text { control/hygiene } \\
\text { requirements }\end{array}$ & Not mentioned \\
\hline (Jofré et al., 2019) & Meat & Retail market & Bacteria & Spain & storage temperature & Microbial cultures \\
\hline (Gkogka et al., 2020) & Meat pies & Production & $\begin{array}{l}\text { Clostridium } \\
\text { perfringens }\end{array}$ & $\begin{array}{c}\text { Netherland } \\
\text { s }\end{array}$ & $\begin{array}{c}\text { Shelf-life/handling of raw } \\
\text { ingredients }\end{array}$ & Not mentioned \\
\hline (Soon, 2019) & Meals & Food vendors & Pathogens & UK & $\begin{array}{l}\text { hygiene facilities and } \\
\text { infrastructure }\end{array}$ & Not mentioned \\
\hline (Szczech et al., 2018) & Vegetables & Production & Bacteria & Poland & $\begin{array}{c}\text { composts/ } \\
\text { fertilization practices }\end{array}$ & Microbial cultures \\
\hline (M. Crotta et al., 2017) & pork meat & Supply chain & $\begin{array}{l}\text { Toxoplasma } \\
\text { gondii }\end{array}$ & UK & $\begin{array}{c}\text { infected } \\
\text { animals/interaction of } \\
\text { parasite with host }\end{array}$ & Modified agglutination test \\
\hline (Valero et al., 2017) & Meals & Catering & Bacteria & Spain & $\begin{array}{l}\text { food handlers and contact } \\
\text { utensils }\end{array}$ & Microbial cultures \\
\hline (Madden et al., 2018) & Meals & Process & $\begin{array}{c}\text { Listeria } \\
\text { monocytogenes }\end{array}$ & UK & $\begin{array}{c}\text { refrigeration temperature/ } \\
\text { sanitizers }\end{array}$ & $\begin{array}{c}\text { Microbial cultures / } \\
\text { Whole genome sequencing }\end{array}$ \\
\hline (Araújo et al., 2017) & Vegetables & Retail market & E.coli & Spain & irrigation water & $\begin{array}{c}\text { Microbial cultures / } \\
\text { PCR }\end{array}$ \\
\hline (Rubini et al., 2018) & Mollusk & Production & $\begin{array}{l}\text { E. coli/ } \\
\text { Salmonella } \\
\text { enterica } \\
\end{array}$ & Italy & $\begin{array}{c}\text { shellfish-growing } \\
\text { waters/environmental } \\
\text { conditions } \\
\end{array}$ & Microbial cultures \\
\hline (Costa et al., 2020) & N.M & Production & $\begin{array}{c}\text { Listeria } \\
\text { monocytogenes }\end{array}$ & Spain & $\begin{array}{l}\text { starter cultures/ } \\
\text { temperature }\end{array}$ & Microbial cultures \\
\hline $\begin{array}{l}\text { (Papadopoulos et al., } \\
\text { 2019) }\end{array}$ & Dairy & Production & S. aureus & Greece & $\begin{array}{c}\text { facilities biofilm/ } \\
\text { sanitizing procedures }\end{array}$ & $\begin{array}{l}\text { Microbial cultures / } \\
\text { PCR }\end{array}$ \\
\hline (Bailey et al., 2018) & Poultry & Production & Campylobacter & UK & $\begin{array}{l}\text { partial depopulation } \\
\text { /season }\end{array}$ & Microbial cultures \\
\hline (Banach et al., 2018) & Lettuce & Process & E.coli & $\begin{array}{c}\text { Netherland } \\
\mathrm{s}\end{array}$ & washing tank & Microbial cultures \\
\hline $\begin{array}{l}\text { (Juliana L.P. Santos et } \\
\text { al., 2018) }\end{array}$ & $\begin{array}{l}\text { Strawberry } \\
\text { puree }\end{array}$ & Process & $\begin{array}{l}\text { Byssochlamys } \\
\text { fulva/nivea }\end{array}$ & Belgium & $\begin{array}{l}\text { heat process, stored } \\
\text { temperature, }{ }^{\circ} \text { Brix and } \\
\text { oxygen concentration }\end{array}$ & Microbial cultures \\
\hline (Castro et al., 2017) & Milk & Manufacture & $\begin{array}{c}\text { Listeria } \\
\text { monocytogenes }\end{array}$ & Finland & $\begin{array}{c}\text { refrigaration temperature/ } \\
\text { handling }\end{array}$ & $\begin{array}{c}\text { Microbial cultures / } \\
\text { PCR }\end{array}$ \\
\hline (Utaaker et al., 2017) & Vegetables & $\begin{array}{c}\text { Retail } \\
\text { market/Street } \\
\text { vendors }\end{array}$ & $\begin{array}{c}\text { Cryptosporidiu } \\
\mathrm{m} / \\
\text { Giardia }\end{array}$ & Norway & $\begin{array}{c}\text { animals/ } \\
\text { consumers handling }\end{array}$ & PCR \\
\hline $\begin{array}{l}\text { (Carvalho Santos et al., } \\
\text { 2017) }\end{array}$ & $\begin{array}{l}\text { Sheep } \\
\text { butter }\end{array}$ & Production & Bacteria & Portugal & manufacturing process & Microbial cultures \\
\hline $\begin{array}{l}\text { (Benítez-Cabello et al., } \\
\text { 2019) }\end{array}$ & $\begin{array}{l}\text { Table } \\
\text { olives }\end{array}$ & Production & Bacteria & Spain & $\begin{array}{c}\text { seasoning and salt } \\
\text { material in packaging }\end{array}$ & xt Generation Sequencin \\
\hline
\end{tabular}




\begin{tabular}{|c|c|c|c|c|c|c|}
\hline & Matrix & $\begin{array}{l}\text { Production } \\
\text { Phase }\end{array}$ & Pathogen & Country & Risk Factor & Technology \\
\hline $\begin{array}{l}\text { (Juliana Lane Paixão dos } \\
\text { Santos et al., 2018) }\end{array}$ & Fruits & Process & Moulds & Belgium & pasteurization & $\begin{array}{c}\text { Microbial cultures / } \\
\text { PCR }\end{array}$ \\
\hline (Caradonna et al., 2017) & Salads & $\begin{array}{l}\text { Manufacture/ } \\
\text { Retail market }\end{array}$ & Parasites & Italy & Agricultural practices & qPCR/NGS \\
\hline $\begin{array}{l}\text { (González-Tejedor et al., } \\
\text { 2018) }\end{array}$ & Smoothies & Retail market & $\begin{array}{c}\text { Listeria } \\
\text { monocytogenes }\end{array}$ & Spain & storage temperature, $\mathrm{pH}$ & Microbial cultures \\
\hline (Zuber et al., 2019) & pork meat & Process & $\begin{array}{c}\text { Listeria } \\
\text { monocytogenes }\end{array}$ & $\begin{array}{c}\text { Montenegr } \\
\mathrm{o}\end{array}$ & infected animals & $\begin{array}{c}\text { Microbial cultures / } \\
\text { Whole genome sequencin }\end{array}$ \\
\hline
\end{tabular}

\subsection{Food Type}

Publications included in this systematic review are categorized by food product examined. According to Fig.2 the highest percentage of studies, presented microbiological risk assessments targeted to crops (fruits and vegetables). More in detail, 19 articles examined a variety of vegetables such as peppers, lettuce, spinach, while 7 works examined fruits such as strawberries and raspberries. In addition, 20 articles referred to microbiological risk factors of dairy products, such as milk and cheese. The aim of 13 works was to investigate microbiological factors associated to meat industry such as pork meat and sausages. Furthermore, the main subject of 9 publications was about seafood's pathogens and factors. Finally, 6 articles presented microbiological risk factors regarding poultry. Additionally, 5 articles included in this work, used prepared meals as matrix.

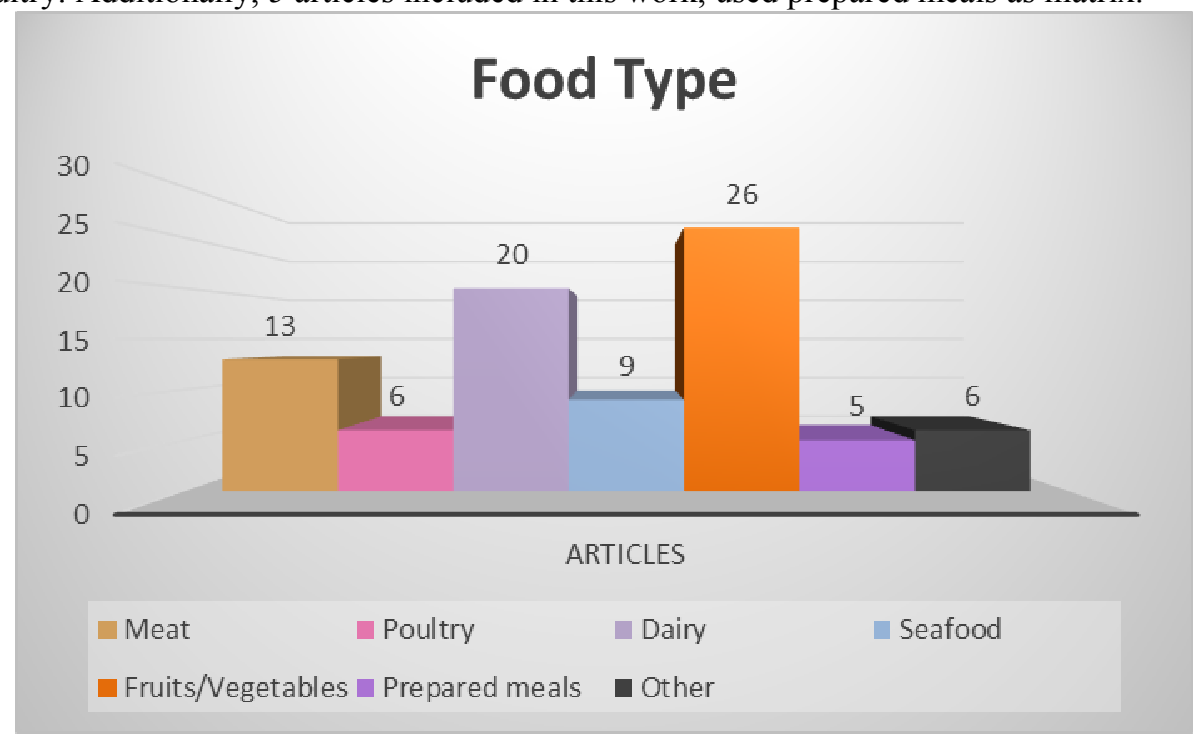

Figure 2. Number of publications according to the food type examined

\subsection{Pathogens}

The reports described in this systematic review, pinpoint one specific foodborne pathogen to investigate, while some articles are focused on a variety of microorganisms (Fig.3). For instance, most articles included, deal with information about Listeria monocytogenes occurrence. Risk factors for E. coli occurrence was the main subject of 8 publications. Furthermore, 6 out of 84 articles, focused on factors related to Campylobacter growth (Bailey et al., 2018; Duqué et al., 2018, 2021; Iannetti et al., 2020; Lytou et al., 2020; Reich et al., 2018). Similarly, 6 articles explored risk factors about Salmonella spp. contamination (Devleesschauwer et al., 2017; Guillén et al., 2020; Iannetti et al., 2020; Kapetanakou et al., 2019; Lytou et al., 2020; Rubini et al., 2018). Finally, 4 works were studied S. aureus, while 2 works studied Vibrio spp. (Bogdanovičová et al., 2017; Dinh Thanh et al., 2017; Papadopoulos et al., 2019; Rahman et al., 2017; Ripolles-Avila et al., 2019; Zampieri et al., 2020). As far as viruses concerns, articles aimed to examine factors associated to Hepatitis A, Hepatitis E and Norovirus presence in food products (Fernandez-Cassi et al., 2017; Li et al., 2018; Pérez-Rodríguez et al., 2019; Santarelli et al., 2018). Regarding parasites, 4 articles demonstrated factors responsible for the occurrence of Toxoplasma gondii, Trichinella spp. Cryptosporidium spp. and Giardia duodenalis (Alvseike et al., 2018; Caradonna et al., 2017; M. Crotta et al., 2017; Utaaker et al., 2017). Last but not least, growth and occurrence of Aspergillus fischeri and Byssochlamys fulva/nivea were presented in 3 articles (Juliana Lane Paixão dos Santos et al., 2018, 2020; Juliana L.P. Santos et al., 2018). 


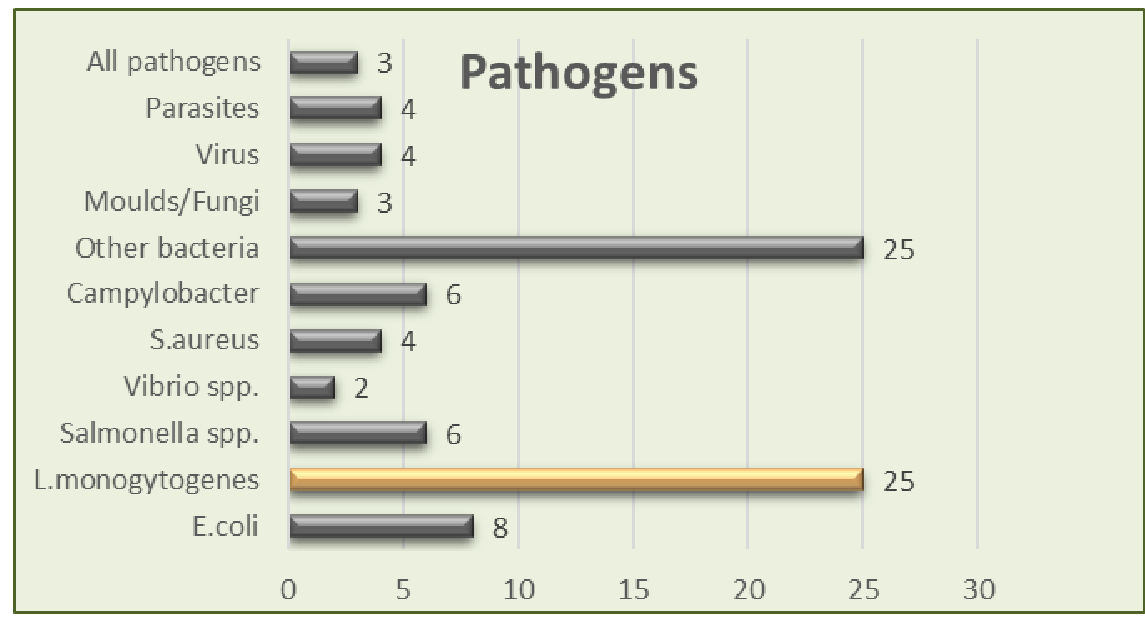

Figure 3. Number of publications according to foodborne pathogen examined

\subsection{Country}

According to Fig. 4, from studies included in this review, Spain holds the lead, following by Italy. Spain was the first country in publications related to microbiological risk assessments with total 21 studies. For example, studies about the presence of $E$. coli in baby spinach or viral contamination on fresh parsley are published (Allende et al., 2017; Fernandez-Cassi et al., 2017). On the other hand, Italy has also contributed to issues related to microbiological risk factors with 12 publications. Articles focused on Listeria monocytogenes in shrimp cocktails or Salmonella enterica in mollusks were included in this review (Rubini et al., 2018; Tirloni et al., 2020). Belgium, UK, Greece, France and Germany are countries with approximately 8 studies regarding microbiological risk factors of food products. Netherlands, Portugal and Norway have published 3 works, during this period. Only one study took place in countries such as Finland, Poland, Montenegro, Ireland, Cyprus, Chest Republic.

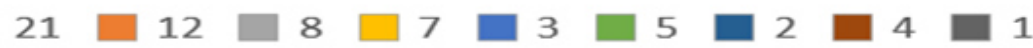

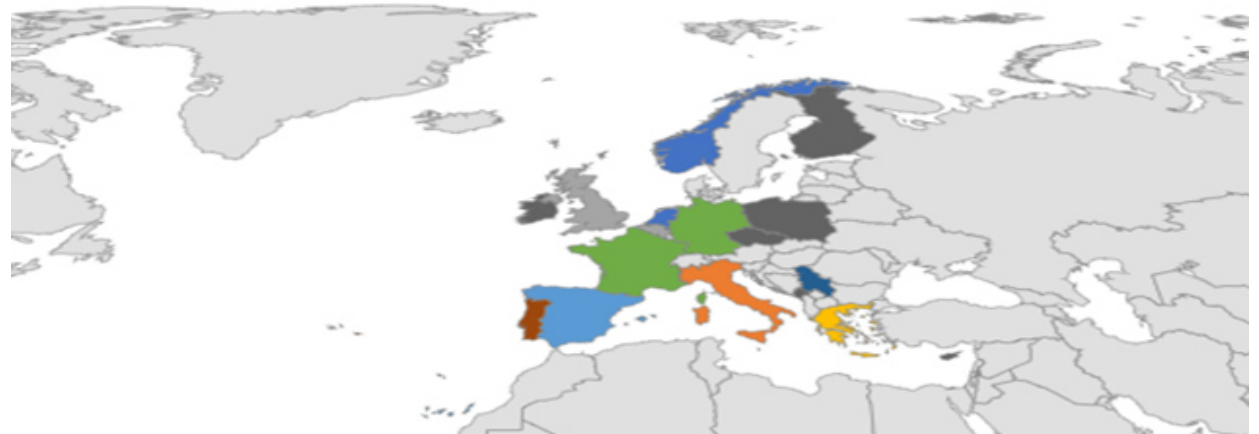

Figure 4. Origin countries of publications on microbiological risk assessment

\subsection{Technology}

The techniques applied for detection of foodborne pathogens are presented in Fig.5. Most of the studies have conducted microbiological cultures for detection of foodborne pathogens. More in detail, for this purpose, 66 articles used culture dependent technique as gold standard methods. More specific, 42 studies selected only gold standard methods for their experiments, while the other used a combination of culture-dependent and cultureindependent techniques. Microbial cultures were performed for assessment of gram-negative bacteria associated with traditional French cheeses or for spoilage risk assessment of pasteurized strawberry purees by Aspergillus fischeri (Imran et al., 2019; Juliana Lane Paixão dos Santos et al., 2020). Moreover, 22 out of all articles included, used Next Generation Sequencing approaches for identification of microorganisms such as Listeria monocytogenes in cold-smoked salmon or Vibrio spp. in Manila clams (Heir et al., 2019; Zampieri et al., 2020). Polymerase chain reaction and similar methods (multiplex PCR, qPCR digital PCR) were applied in 17 studies, 
as tools for detection and verification of pathogens. For example, PCR was performed for detection of Cryptosporidium and Giardia in vegetables, while qPCR for foodborne viruses in berries (Li et al., 2018; Utaaker et al., 2017). Finally, in 7 studies included either do not mentioned applied technology or an alternative methodology was used such as PCR-Denaturing Gradient Gel Electrophoresis (PCR-DGGE), Multilocus sequence analysis (MLSA) and Multilocus sequence typing(MLST).

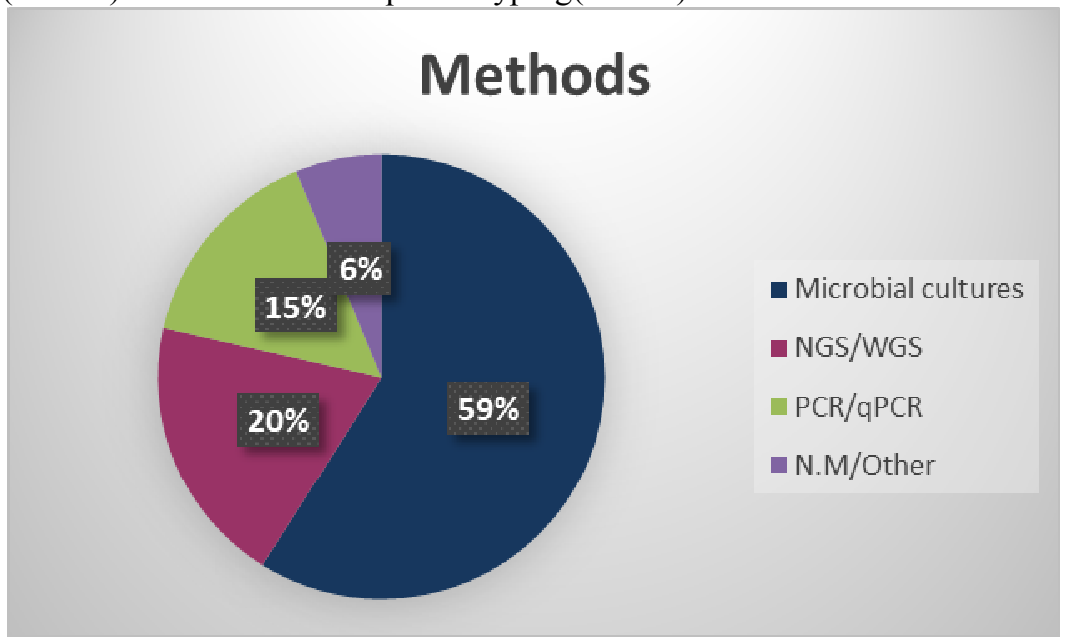

Figure 5. Number of publications according to methodology applied for detection of foodborne pathogens

\subsection{Risk factors}

Depending on the type of food sample, a variety of risk factors were highlighted for foodborne pathogens contamination. Figure 6. depicts microbiological risk factors reported in correlation to food type. As far as fruits and vegetables concerns, most common risk factors mentioned, were irrigation water, processing practices and storage temperature, following by fertilizations practices and compost, washing, and food handling regarding hygiene(Banach et al., 2018; Fernandez-Cassi et al., 2017; López-Gálvez et al., 2020). Some studies pointed out the importance of plant species and tissue type for risk contamination or how humidity in farms can affect the growth of foodborne pathogens (Devleesschauwer et al., 2017; Merget, B., Forbes, K. J., Brennan, F., McAteer, S., Shepherd, T., Strachan, N. J., \& Holden, 2019; Wright \& Holden, 2018). For meat products such as beef and pork, infected animals were indicated as the highest microbiological risk factor. Regarding poultry, infected animals was the most referred risk factor, as well. Also, slaughter line, storage temperature and shelf life considered to be potential risk factors for meat products contamination. More in detail, niches in production of meat products, were responsible for Listeria monocytogenes contamination (Lüth et al., 2020). Storage temperature and selection of starter cultures for dairy products, were reported as risk factors. Furthermore, ripening stage, manufacturing processes and surface biofilms are presented in the articles included. Storage conditions proved to affect microbiological quality of seafood, poultry and prepared meals. Although, washing step was the most common risk factor reported, regarding prepared meals. 


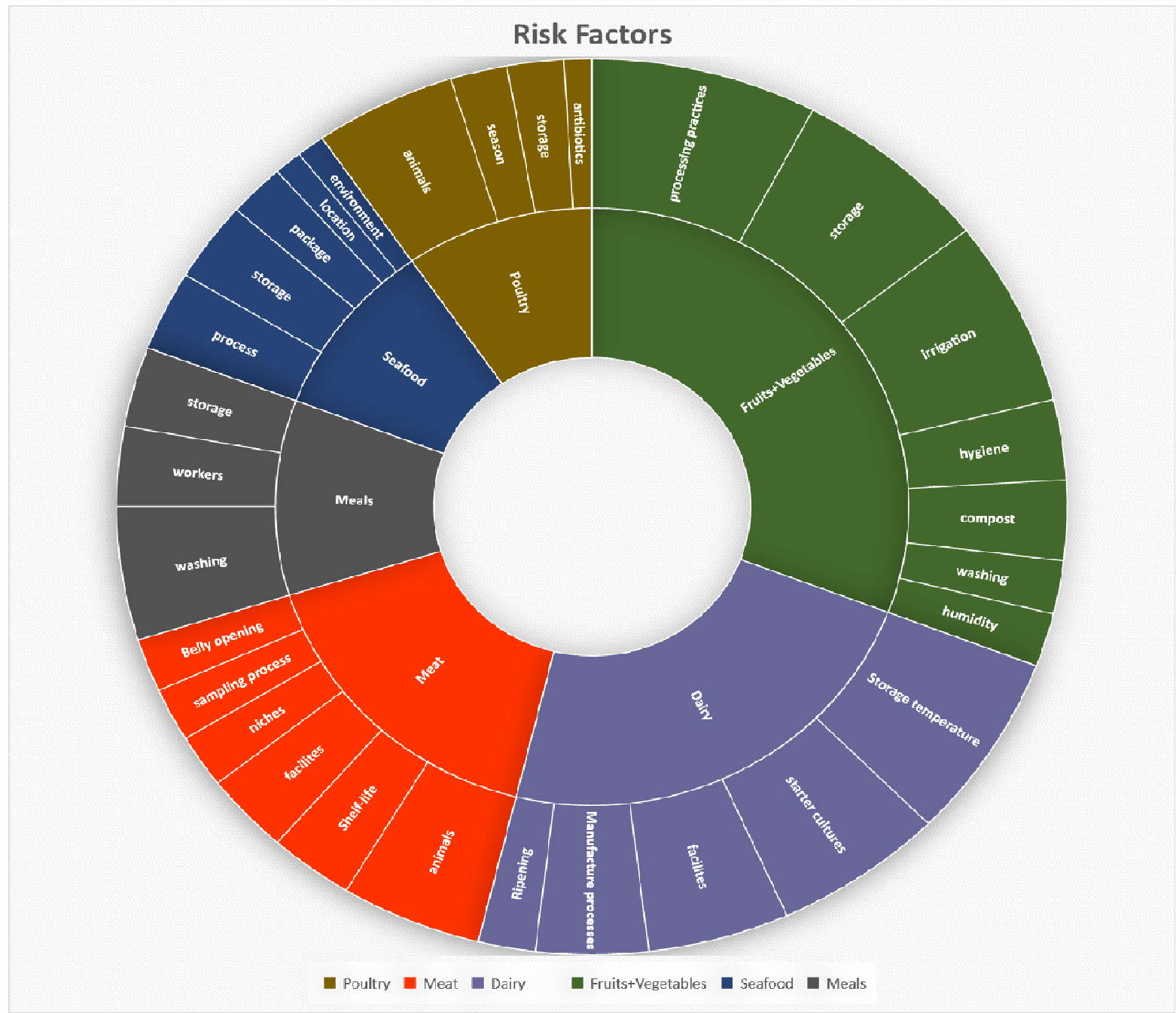

Figure 6. Microbiological Risk factors of each food type

\section{Discussion}

The current systematic review sought to synthesize quantitative evidence regarding microbiological risk factors in food industry in Europe. Food type, foodborne pathogen, country and technology are presented as well.

Most of the studies included, examined microbiological risk factors, about fruits and vegetables. This can be explained by the fact, that fruits and vegetables are often consumed raw (Balali et al., 2020). The last decade, fruits and vegetables consumption increased as a result of healthier lifestyle (Machado-Moreira et al., 2019). Furthermore, some procedures in production may cause damage in tissue plants and therefore, these food products can be easily contaminated by microorganisms (Kaczmarek et al., 2019). Thus, it is essential need for scientists to focus on this food type and examine all the factors involved.

The majority of the studies focused on contamination of food products by Listeria monocytogenes. Listeria monocytogenes considered to be an important food associated-pathogen due to the fact that it can adapt, survive and multiple in a variety of environments such as low $\mathrm{pH}$, refrigeration temperatures and high salt concentration (Ballom et al., 2020; Marik et al., 2020; Sheng et al., 2017; Smith et al., 2018). There are numerous works that studied contamination routes or ecology and physiology of Listeria monocytogenes in a great range of food products. Seafood and aquatic products, fresh produce, milk, meat, cheese are some food types already examined (Castro et al., 2018; Honjoh et al., 2018; Selvaganapathi et al., 2018).

Spain is the leader country regarding microbiological risk factors in foodstuff, with 21 publications. There are many surveys which indicated that further prevention strategies against foodborne pathogens, should be developed in Spain (Arnedo-Pena et al., 2016; Ballesté-Delpierre \& Vila Estapé, 2016; Herrador et al., 2019; Letchumanan et al., 2019; Romalde et al., 2018). Additionally, authors highlighted that targeted prevention such as food safety education or upgraded industrial measures should be prioritized. Studies included in this systematic review revealed that Spain has the highest number of reports, followed by Italy with 12 publications about microbiological risk factors. A great variety of food products, which hold quality schemes from European 
Union, take place in Italy. Therefore, last decade, Italy has emerged in the field of food safety and quality (Dimitrakopoulou \& Vantarakis, 2021).

Culture-dependent techniques are traditionally used for pathogens detection in food samples. However, culture-independent techniques have been developed in order to face up existing limitations and challenges (Dimitrakopoulou et al., 2021). DNA based and immunological methods are alternative and validated tools that have already utilized in food industry (Rohde et al., 2017). For example, Next Generation Sequencing approaches provide more information about microbial profiling of a food product (Fanning et al., 2017; Ronholm, 2018). Therefore, technology used will influence pathogens detection. A key solution for this issue, would be the application of both culture-dependent and independent techniques (Dissanayake et al., 2018; Fenske et al., 2020; Zampieri et al., 2021).

In terms of risk factors, our results are in agreement to a study conducted in 2018 about sources and contamination routes of microorganisms to fresh produce, which evidenced irrigation water and soil, as well (Alegbeleye et al., 2018). Disinfection treatments of water as intervention strategy could be applied and positively affect total microbiota (Dandie et al., 2020; Truchado et al., 2018). Furthermore, there are several studies which highlighted, that biological soil amendments are as also a potential source for pathogens in fresh produce (Iwu \& Okoh, 2019; Sharma \& Reynnells, 2018). Implementation of bacteriophages technology in pre and post-harvest processes could be an alternative solution to control pathogens in fresh produce (López-Cuevas et al., 2021).

In contrast, infected animals, facilities and storage conditions are risk factors for meat contamination. These findings are similar to studies, which were conducted in order to present microbiological risk factors of the meat chain and underlined contamination sources (Fasanmi et al., 2018; Rosette et al., 2019; Zwirzitz et al., 2020). Infected animals can be source for poultry contamination, as well (Heredia \& García, 2018). Antimicrobial use in animal husbandries is proposed as prevention strategy for animal origin foods (Pérez-Rodríguez \& Mercanoglu Taban, 2019). Moreover, risk factors for poultry contamination can be storage temperature and long-term food storages (Duqué et al., 2021; Lytou et al., 2020). Storage temperature considered to be a high risk for pathogens growth in dairy products, too (Lianou et al., 2018; Papadopoulou et al., 2018). Intelligent packages which contain time-temperature indicators could be utilized in food industry and provide information about storage stability of a food product throughout the supply chain (Alfei et al., 2020; Ndraha et al., 2018). Interestingly, starter cultures used for dairy products production are associated to quality and safety (El-Hajjaji et al., 2020b; Gérard et al., 2020b; Imran et al., 2019). The role of microbial starters for products such as milk , cheese and yoghurt in terms of safety and quality , considered to be crucial (Russo et al., 2017). Therefore, special attention should be given to starter culture selected for dairy products (Motawee \& Neveen, 2016). Finally, our results are in agreement with a study about microbiological risk factors in diary facilities, that pointed out storage temperature and hygiene of environment and equipment are crucial. In general, better knowledge and understanding of food safety issues are suggested as an additional preventative measure (Phiri et al., 2021).

Storage conditions, process line, packaging and environment resulted as responsible factors for sea products contamination. Naturally occurring pathogens in aquatic environments are reported in several studies as risk factor for seafood (Afreen \& Ucak, 2021; Ali et al., 2020; Pumipuntu \& Indrawattana, 2017). Furthermore, seafood contamination during processing, storage and packaging is also a challenge, that managers are trying to face up by utilizing Good Manufacturing Practice (GMP), Good Hygiene Practice (GHP) and Hazard Analysis and Critical Control Point (HACCP) systems (Elbashir et al., 2018). For instance, refrigerated storage can affect growth of Listeria monocytogenes in seafood (Dumen et al., 2020). Continued surveillance system could be important for future prevention efforts.

Finally, microbiological risk factors for prepared meals considered to be poor hygiene of workers, storage conditions and washing, especially for foods that not subjected in any heat treatment (Valero et al., 2016).

Therefore, it is essential need to evaluate all available information about risk factors, microorganisms and food products and finally, fulfil gaps regarding food safety and food quality. It is evidenced, that all data for risk factors of contamination each food type by potential pathogens should be further examined, so that the already existing managements systems could be upgraded by effective control measures. Definitively, by cultureindependent techniques, extra information about foodborne pathogens and routes of contamination are obtained. Thus, utilization of advanced methods in food industry could be considered as an added-value under the riskbased food safety management framework.

\section{Conclusion}

Based on this systematic review of the literature, potential microbiological risk factors in terms of food quality and safety, were summarized and presented. In conclusion, our analysis can provide risk managers and public authorities, an overview of microbiological risk factors, from "farm to fork". Implementation of effective risk management systems in food industry could contribute to identify and eliminate potential risks and thus, 
consumer's health and food quality could be reassured. Therefore, our findings could provide managers in food industry either to build up more effective management systems or even help scientists to better understand ecology of pathogens regarding food matrix and environmental conditions. Moreover, omics technologies such as WGS or NGS, considered to be very promising, addressing issues regarding foodborne pathogens in supply chain and should be incorporated into risk assessments strategies. These tools could open up new perspectives in microbiological hazard identification, such as better understanding of foodborne pathogen dynamics or pathogens variability. Further studies regarding the development and practical application of improved measures in managements systems and survival of pathogens in complex matrices are recommended.

Author Contributions: Conceptualization, M.D..; methodology, M.D.; validation, M.D, and A.V.; formal analysis, M.D.; investigation, M.D and A.V.; resources, M.D.; data curation, M.D and A.V.; writing-original draft preparation, M.D.; writing-review and editing, A.V; visualization, M.D.; supervision, A.V; project administration, A.V.; funding acquisition, A.V. All authors have read and agreed to the published version of the manuscript.

Funding: The present research received fund from the Single State Action Aid for Research, Technological Development \& Innovation «INVESTIGATE - CREATE - INNOVATE" project "Trust Trace" T1EDK-04028.

Conflicts of Interest: The authors declare no conflict of interest.

\section{References}

Afreen, M., \& Ucak, I. (2021). Food-borne Pathogens in Seafood. 1, 44-58.

Akineden, Ö., Heinrich, V., Gross, M., \& Usleber, E. (2017). Reassessment of Cronobacter spp. originally isolated as Enterobacter sakazakii from infant food. Food Microbiology, 65, 44-50. https://doi.org/10.1016/j.fm.2017.01.021

Alegbeleye, O. O., Singleton, I., \& Sant'Ana, A. S. (2018). Sources and contamination routes of microbial pathogens to fresh produce during field cultivation: A review. Food Microbiology, 73, 177-208. https://doi.org/10.1016/j.fm.2018.01.003

Alfei, S., Marengo, B., \& Zuccari, G. (2020). Nanotechnology application in food packaging: A plethora of opportunities versus pending risks assessment and public concerns. Food Research International, 137(August), 109664. https://doi.org/10.1016/j.foodres.2020.109664

Ali, A., Parisi, A., Conversano, M. C., Iannacci, A., D’Emilio, F., Mercurio, V., \& Normanno, G. (2020). Foodborne bacteria associated with seafoods: A brief review. Journal of Food Quality and Hazards Control, 7(1), 4-10. https://doi.org/10.18502/JFQHC.7.1.2446

Allende, A., Castro-Ibáñez, I., Lindqvist, R., Gil, M. I., Uyttendaele, M., \& Jacxsens, L. (2017). Quantitative contamination assessment of Escherichia coli in baby spinach primary production in Spain: Effects of weather conditions and agricultural practices. International Journal of Food Microbiology, 257(May 2015), 238-246. https://doi.org/10.1016/j.ijfoodmicro.2017.06.027

Alvseike, O., Prieto, M., Torkveen, K., Ruud, C., \& Nesbakken, T. (2018). Meat inspection and hygiene in a Meat Factory Cell - An alternative concept. Food Control, 90, 32-39. https://doi.org/10.1016/j.foodcont.2018.02.014

Araújo, S., A.T. Silva, I., Tacão, M., Patinha, C., Alves, A., \& Henriques, I. (2017). Characterization of antibiotic resistant and pathogenic Escherichia coli in irrigation water and vegetables in household farms. International Journal of Food Microbiology, 257(June), $192-200$. https://doi.org/10.1016/j.ijfoodmicro.2017.06.020

Arnedo-Pena, A., Sabater-Vidal, S., Herrera-León, S., Bellido-Blasco, J. B., Silvestre-Silvestre, E., MeseguerFerrer, N., Yague-Muñoz, A., Gil-Fortuño, M., Romeu-García, A., \& Moreno-Muñoz, R. (2016). An outbreak of monophasic and biphasic Salmonella Typhimurium, and Salmonella Derby associated with the consumption of dried pork sausage in Castellon (Spain). Enfermedades Infecciosas y Microbiologia Clinica, 34(9), 544-550. https://doi.org/10.1016/j.eimc.2015.11.016

Bailey, R. A., Kranis, A., Psifidi, A., Watson, K. A., Rothwell, L., Hocking, P. M., Kaiser, P., Stevens, M. P., \& Avendano, S. (2018). Colonization of a commercial broiler line by Campylobacter is under limited genetic control and does not significantly impair performance or intestinal health. Poultry Science, 97(12), 41674176. https://doi.org/10.3382/ps/pey295

Balali, G. I., Yar, D. D., Afua Dela, V. G., \& Adjei-Kusi, P. (2020). Microbial Contamination, an Increasing Threat to the Consumption of Fresh Fruits and Vegetables in Today's World. International Journal of Microbiology, 2020. https://doi.org/10.1155/2020/3029295

Ballesté-Delpierre, C., \& Vila Estapé, J. (2016). Why are we still detecting food-related Salmonella outbreaks in Spain? Enfermedades Infecciosas y Microbiologia Clinica, 34(9), 541-543. https://doi.org/10.1016/j.eimc.2016.08.001

Ballom, K. F., Tsai, H. C., Taylor, M., Tang, J., \& Zhu, M. J. (2020). Stability of Listeria monocytogenes in nonfat dry milk powder during isothermal treatment and storage. Food Microbiology, 87(September 2019), 
103376. https://doi.org/10.1016/j.fm.2019.103376

Banach, J. L., van Overbeek, L. S., Nierop Groot, M. N., van der Zouwen, P. S., \& van der Fels-Klerx, H. J. (2018). Efficacy of chlorine dioxide on Escherichia coli inactivation during pilot-scale fresh-cut lettuce processing. International Journal of Food Microbiology, 269(December 2017), $128-136$. https://doi.org/10.1016/j.ijfoodmicro.2018.01.013

Beneduce, L., Gatta, G., Bevilacqua, A., Libutti, A., Tarantino, E., Bellucci, M., Troiano, E., \& Spano, G. (2017). Impact of the reusing of food manufacturing wastewater for irrigation in a closed system on the microbiological quality of the food crops. International Journal of Food Microbiology, 260(March), 51-58. https://doi.org/10.1016/j.ijfoodmicro.2017.08.009

Benítez-Cabello, A., Romero-Gil, V., Medina, E., Sánchez, B., Calero-Delgado, B., Bautista-Gallego, J., Jiménez-Díaz, R., \& Arroyo-López, F. N. (2019). Metataxonomic analysis of the bacterial diversity in table olive dressing components. Food Control, 190-197. https://doi.org/10.1016/j.foodcont.2019.05.036

Beuchat, L. R. (2006). Vectors and conditions for preharvest contamination of fruits and vegetables with pathogens capable of causing enteric diseases. British Food Journal, 108(1), 38-53. https://doi.org/10.1108/00070700610637625

Bintsis, T. (2017). Foodborne pathogens. AIMS Microbiology, 3(3), $529-563$. https://doi.org/10.3934/microbiol.2017.3.529

Bogdanovičová, K., Necidová, L., Haruštiaková, D., \& Janštová, B. (2017). Milk powder risk assessment with staphylococcus aureus toxigenic strains. Food Control, $\quad 73, \quad 2-7$. https://doi.org/10.1016/j.foodcont.2016.07.007

Bolívar, A., Costa, J. C. C. P., Posada-Izquierdo, G. D., Valero, A., Zurera, G., \& Pérez-Rodríguez, F. (2018). Modelling the growth of Listeria monocytogenes in Mediterranean fish species from aquaculture production. International Journal of Food Microbiology, 270(December 2017), 14-21. https://doi.org/10.1016/j.ijfoodmicro.2018.02.005

Cadavez, V. A. P., Campagnollo, F. B., Silva, R. A., Duffner, C. M., Schaffner, D. W., Sant'Ana, A. S., \& Gonzales-Barron, U. (2019). A comparison of dynamic tertiary and competition models for describing the fate of Listeria monocytogenes in Minas fresh cheese during refrigerated storage. Food Microbiology, 79(November 2018), 48-60. https://doi.org/10.1016/j.fm.2018.11.004

Caradonna, T., Marangi, M., Del Chierico, F., Ferrari, N., Reddel, S., Bracaglia, G., Normanno, G., Putignani, L., \& Giangaspero, A. (2017). Detection and prevalence of protozoan parasites in ready-to-eat packaged salads on sale in Italy. Food Microbiology, 67, 67-75. https://doi.org/10.1016/j.fm.2017.06.006

Carvalho Santos, I., Pinto, J., Pimenta, A. I., Madureira, J., Matos, P., Viegas, C., Raposo, A., Margaça, F. M. A., \& Cabo Verde, S. (2017). Use of gamma radiation in sheep butter manufacturing process for shelf-life extension. International Dairy Journal, 71, 43-49. https://doi.org/10.1016/j.idairyj.2017.03.003

Castro, H., Jaakkonen, A., Hakkinen, M., Korkeala, H., \& Lindström, M. (2018). Occurrence, persistence, and contamination routes of Listeria monocytogenes genotypes on three Finnish dairy cattle farms: A longitudinal study. Applied and Environmental Microbiology, 84(4). https://doi.org/10.1128/AEM.0200017

Castro, H., Ruusunen, M., \& Lindström, M. (2017). Occurrence and growth of Listeria monocytogenes in packaged raw milk. International Journal of Food Microbiology, 261(June), 1-10. https://doi.org/10.1016/j.ijfoodmicro.2017.08.017

Cocolin, L., Mataragas, M., Bourdichon, F., Doulgeraki, A., Pilet, M. F., Jagadeesan, B., Rantsiou, K., \& Phister, T. (2018). Next generation microbiological risk assessment meta-omics: The next need for integration. International Journal of Food Microbiology, 287(November 2017), 10-17. https://doi.org/10.1016/j.ijfoodmicro.2017.11.008

Correia Peres Costa, J. C., Floriano, B., Bascón Villegas, I. M., Rodríguez-Ruiz, J. P., Posada-Izquierdo, G. D., Zurera, G., \& Pérez-Rodríguez, F. (2020). Study of the microbiological quality, prevalence of foodborne pathogens and product shelf-life of Gilthead sea bream (Sparus aurata) and Sea bass (Dicentrarchus labrax) from aquaculture in estuarine ecosystems of Andalusia (Spain). Food Microbiology, 90(July 2019), 103498. https://doi.org/10.1016/j.fm.2020.103498

Costa, J. C. C. P., Bolívar, A., Valero, A., Carrasco, E., Zurera, G., \& Pérez-Rodríguez, F. (2020). Evaluation of the effect of Lactobacillus sakei strain L115 on Listeria monocytogenes at different conditions of temperature by using predictive interaction models. Food Research International, 131(November 2018), 108928. https://doi.org/10.1016/j.foodres.2019.108928

Crotta, M., Limon, G., Blake, D. P., \& Guitian, J. (2017). Knowledge gaps in host-parasite interaction preclude accurate assessment of meat-borne exposure to Toxoplasma gondii. International Journal of Food Microbiology, 261, 95-101. https://doi.org/10.1016/j.ijfoodmicro.2016.12.010

Crotta, Matteo, Luisi, E., Dadios, N., \& Guitian, J. (2019). Probabilistic modelling of events at evisceration 
during slaughtering of pigs using expert opinion: Quantitative data in support of stochastic models of risk of contamination. Microbial Risk Analysis, 11(January 2018), 57-65. https://doi.org/10.1016/j.mran.2018.10.001

Dandie, C. E., Ogunniyi, A. D., Ferro, S., Hall, B., Drigo, B., Chow, C. W. K., Venter, H., Myers, B., Deo, P., Donner, E., \& Lombi, E. (2020). Disinfection options for irrigation water: Reducing the risk of fresh produce contamination with human pathogens. Critical Reviews in Environmental Science and Technology, 50(20), 2144-2174. https://doi.org/10.1080/10643389.2019.1704172

den Besten, H. M. W., Amézquita, A., Bover-Cid, S., Dagnas, S., Ellouze, M., Guillou, S., Nychas, G., O’Mahony, C., Pérez-Rodriguez, F., \& Membré, J. M. (2018). Next generation of microbiological risk assessment: Potential of omics data for exposure assessment. International Journal of Food Microbiology, 287(October 2017), 18-27. https://doi.org/10.1016/j.ijfoodmicro.2017.10.006

Devleesschauwer, B., Marvasi, M., Giurcanu, M. C., Hochmuth, G. J., Speybroeck, N., Havelaar, A. H., \& Teplitski, M. (2017). High relative humidity pre-harvest reduces post-harvest proliferation of Salmonella in tomatoes. Food Microbiology, 66, 55-63. https://doi.org/10.1016/j.fm.2017.04.003

Díaz-Jiménez, D., García-Meniño, I., Fernández, J., García, V., \& Mora, A. (2020). Chicken and turkey meat: Consumer exposure to multidrug-resistant Enterobacteriaceae including mcr-carriers, uropathogenic E. coli and high-risk lineages such as ST131. International Journal of Food Microbiology, 331(June), 108750. https://doi.org/10.1016/j.ijfoodmicro.2020.108750

Dimitrakopoulou, M.-E., Kotsalou, C., Stavrou, V., \& Vantarakis, A. (2021). Advancing quality control of food samples by Next Generation Sequencing compared to culture-dependent techniques. Journal of Food Science and Nutrition Research, 04(02), 118-130. https://doi.org/10.26502/jfsnr.2642-11000066

Dimitrakopoulou, M.-E., \& Vantarakis, A. (2021). Does Traceability Lead to Food Authentication? A Systematic Review from A European Perspective. Food Reviews International, 00(00), 1-23. https://doi.org/10.1080/87559129.2021.1923028

Dinh Thanh, M., Frentzel, H., Fetsch, A., Appel, B., \& Mader, A. (2017). Impact of spiking techniques on the survival of Staphylococcus aureus in artificially contaminated condiments. Food Control, 73, 117-126. https://doi.org/10.1016/j.foodcont.2016.10.021

Dissanayake, A. J., Purahong, W., Wubet, T., Hyde, K. D., Zhang, W., Xu, H., Zhang, G., Fu, C., Liu, M., Xing, Q., Li, X., \& Yan, J. (2018). Direct comparison of culture-dependent and culture-independent molecular approaches reveal the diversity of fungal endophytic communities in stems of grapevine (Vitis vinifera). Fungal Diversity, 90(1), 85-107. https://doi.org/10.1007/s13225-018-0399-3

Dumen, E., Ekici, G., Ergin, S., \& Bayrakal, G. M. (2020). Presence of Foodborne Pathogens in Seafood and Risk Ranking for Pathogens. Foodborne Pathogens and Disease, 17(9), 541-546. https://doi.org/10.1089/fpd.2019.2753

Duqué, B., Canon, J., Haddad, N., Guillou, S., \& Membré, J. M. (2021). Quantitative approach to assess the compliance to a performance objective (PO) of Campylobacter jejuni in poultry meat in France. International Journal of Food Microbiology, 336. https://doi.org/10.1016/j.ijfoodmicro.2020.108916

Duqué, B., Daviaud, S., Guillou, S., Haddad, N., \& Membré, J. M. (2018). Quantification of Campylobacter jejuni contamination on chicken carcasses in France. Food Research International, 106(December 2017), 1077-1085. https://doi.org/10.1016/j.foodres.2017.12.017

El-Hajjaji, S., Gérard, A., De Laubier, J., Di Tanna, S., Lainé, A., Patz, V., \& Sindic, M. (2020a). Assessment of growth and survival of Listeria monocytogenes in raw milk butter by durability tests. International Journal of Food Microbiology, 321(February 2019), 108541. https://doi.org/10.1016/j.ijfoodmicro.2020.108541

El-Hajjaji, S., Gérard, A., De Laubier, J., Di Tanna, S., Lainé, A., Patz, V., \& Sindic, M. (2020b). Assessment of growth and survival of Listeria monocytogenes in raw milk butter by durability tests. International Journal of Food Microbiology, 321(January), 108541. https://doi.org/10.1016/j.ijfoodmicro.2020.108541

Elbashir, S., Parveen, S., Schwarz, J., Rippen, T., Jahncke, M., \& DePaola, A. (2018). Seafood pathogens and information on antimicrobial resistance: A review. Food Microbiology, 70, 85-93. https://doi.org/10.1016/j.fm.2017.09.011

European Parliament and Council. (2018). REGULATION (EU) 2019/1381 OF THE EUROPEAN PARLIAMENT AND OF THE COUNCIL of 20 June 2019 on the transparency and sustainability of the EU risk assessment in the food chain and amending Regulations (EC) No 178/2002, (EC) No 1829/2003, (EC) No 1831/2003, (EC. Official Journal of the European Communities, L231(68), 48-119.

Evert-Arriagada, K., Trujillo, A. J., Amador-Espejo, G. G., \& Hernández-Herrero, M. M. (2018). High pressure processing effect on different Listeria spp. in a commercial starter-free fresh cheese. Food Microbiology, 76(March 2017), 481-486. https://doi.org/10.1016/j.fm.2018.07.012

Fanning, S., Proos, S., Jordan, K., \& Srikumar, S. (2017). A review on the applications of next generation sequencing technologies as applied to food-related microbiome studies. Frontiers in Microbiology, 8(SEP), 1-16. https://doi.org/10.3389/fmicb.2017.01829 
FAO/WHO. (2021). Microbiological risk assessment Guidance for Food.

FAO. (2020). FAO Guide to Ranking Food Safety Risks at the National Level. In FAO Guide to Ranking Food Safety Risks at the National Level. https://doi.org/10.4060/cb0887en

Fasanmi, O. G., Makinde, G. E. O., Popoola, M. A., Fasina, O. F., Matere, J., Kehinde, O. O., Balogun, F. A., \& Ogundare, S. T. (2018). Potential risk factors associated with carcass contamination in slaughterhouse operations and hygiene in Oyo state, Nigeria. International Journal of Livestock Production, 9(8), 211-220. https://doi.org/10.5897/ijlp2018.0491

Fenske, G. J., Ghimire, S., Antony, L., Christopher-Hennings, J., \& Scaria, J. (2020). Integration of culturedependent and independent methods provides a more coherent picture of the pig gut microbiome. FEMS Microbiology Ecology, 96(3), 1-10. https://doi.org/10.1093/femsec/fiaa022

Fernandez-Cassi, X., Timoneda, N., Gonzales-Gustavson, E., Abril, J. F., Bofill-Mas, S., \& Girones, R. (2017). A metagenomic assessment of viral contamination on fresh parsley plants irrigated with fecally tainted river water. International Journal of Food Microbiology, 257(December 2016), 80-90. https://doi.org/10.1016/j.ijfoodmicro.2017.06.001

Filipello, V., Mughini-Gras, L., Gallina, S., Vitale, N., Mannelli, A., Pontello, M., Decastelli, L., Allard, M. W., Brown, E. W., \& Lomonaco, S. (2020). Attribution of Listeria monocytogenes human infections to food and animal sources in Northern Italy. Food Microbiology, 89(June 2019), 103433. https://doi.org/10.1016/j.fm.2020.103433

Fritsch, L., Felten, A., Palma, F., Mariet, J. F., Radomski, N., Mistou, M. Y., Augustin, J. C., \& Guillier, L. (2019). Insights from genome-wide approaches to identify variants associated to phenotypes at pan-genome scale: Application to L. monocytogenes' ability to grow in cold conditions. International Journal of Food Microbiology, 291(November 2018), 181-188. https://doi.org/10.1016/j.ijfoodmicro.2018.11.028

Fung, F., Wang, H. S., \& Menon, S. (2018). Food safety in the 21st century. Biomedical Journal, 41(2), 88-95. https://doi.org/10.1016/j.bj.2018.03.003

Garayoa, R., Abundancia, C., Díez-Leturia, M., \& Vitas, A. I. (2017). Essential tools for food safety surveillance in catering services: On-site inspections and control of high risk cross-contamination surfaces. Food Control, 75, 48-54. https://doi.org/10.1016/j.foodcont.2016.12.032

Garre, A., González-Tejedor, G. A., Aznar, A., Fernández, P. S., \& Egea, J. A. (2019). Mathematical modelling of the stress resistance induced in Listeria monocytogenes during dynamic, mild heat treatments. Food Microbiology, 84(June), 103238. https://doi.org/10.1016/j.fm.2019.06.002

Gérard, A., El-Hajjaji, S., Van Coillie, E., Bentaïb, A., Daube, G., \& Sindic, M. (2020a). Determination of the growth potential of Listeria monocytogenes in various types of Belgian artisanal cheeses by challenge tests. Food Microbiology, 92(June). https://doi.org/10.1016/j.fm.2020.103582

Gérard, A., El-Hajjaji, S., Van Coillie, E., Bentaïb, A., Daube, G., \& Sindic, M. (2020b). Determination of the growth potential of Listeria monocytogenes in various types of Belgian artisanal cheeses by challenge tests. Food Microbiology, 92(January). https://doi.org/10.1016/j.fm.2020.103582

Gkogka, E., Reij, M. W., Gorris, L. G. M., \& Zwietering, M. H. (2020). Risk assessment of Clostridium perfringens in Cornish pasties in the UK. Food Control, 108(June 2019), 106822. https://doi.org/10.1016/j.foodcont.2019.106822

Gonzales-Barron, U., Campagnollo, F. B., Schaffner, D. W., Sant'Ana, A. S., \& Cadavez, V. A. P. (2020). Behavior of Listeria monocytogenes in the presence or not of intentionally-added lactic acid bacteria during ripening of artisanal Minas semi-hard cheese. Food Microbiology, 91(September 2019). https://doi.org/10.1016/j.fm.2020.103545

González-Tejedor, G. A., Garre, A., Esnoz, A., Artés-Hernández, F., \& Fernández, P. S. (2018). Effect of storage conditions in the response of Listeria monocytogenes in a fresh purple vegetable smoothie compared with an acidified TSB medium. Food Microbiology, 72, 98-105. https://doi.org/10.1016/j.fm.2017.11.005

Guillén, S., Marcén, M., Mañas, P., \& Cebrián, G. (2020). Differences in resistance to different environmental stresses and non-thermal food preservation technologies among Salmonella enterica subsp. enterica strains. Food Research International, 132(October 2019), 109042. https://doi.org/10.1016/j.foodres.2020.109042

Heir, E., Liland, K. H., Carlehög, M., \& Holck, A. L. (2019). Reduction and inhibition of Listeria monocytogenes in cold-smoked salmon by Verdad N6, a buffered vinegar fermentate, and UV-C treatments. International Journal of Food Microbiology, 291(November 2018), 48-58. https://doi.org/10.1016/j.ijfoodmicro.2018.10.026

Heredia, N., \& García, S. (2018). Animals as sources of food-borne pathogens: A review. Animal Nutrition, 4(3), 250-255. https://doi.org/10.1016/j.aninu.2018.04.006

Herrador, Z., Gherasim, A., López-Vélez, R., \& Benito, A. (2019). Listeriosis in Spain based on hospitalisation records, 1997 to 2015: Need for greater awareness. Eurosurveillance, 24(21), 1-10. https://doi.org/10.2807/1560-7917.ES.2019.24.21.1800271

Honjoh, K. I., Lin, Y., Jo, K., Iwaizako, Y., Maeda, M., Kijima, N., \& Miyamoto, T. (2018). Possible 
contamination routes of listeria monocytogenes in leaf lettuce during cultivation. Food Science and Technology Research, 24(5), 911-920. https://doi.org/10.3136/fstr.24.911

Iannetti, L., Neri, D., Santarelli, G. A., Cotturone, G., Podaliri Vulpiani, M., Salini, R., Antoci, S., Di Serafino, G., Di Giannatale, E., Pomilio, F., \& Messori, S. (2020). Animal welfare and microbiological safety of poultry meat: Impact of different at-farm animal welfare levels on at-slaughterhouse Campylobacter and Salmonella contamination. Food Control, 109(September 2019). https://doi.org/10.1016/j.foodcont.2019.106921

Imran, M., Desmasures, N., Coton, M., Coton, E., Le Flèche-Matéos, A., Irlinger, F., Delbès-Paus, C., Stahl, V., Montel, M. C., \& Vernoux, J. P. (2019). Safety assessment of Gram-negative bacteria associated with traditional French cheeses. Food Microbiology, 79(September 2018), 1-10. https://doi.org/10.1016/j.fm.2018.11.001

Iwu, C. D., \& Okoh, A. I. (2019). Preharvest transmission routes of fresh produce associated bacterial pathogens with outbreak potentials: A review. International Journal of Environmental Research and Public Health, 16(22). https://doi.org/10.3390/ijerph16224407

Jansen, W., Linard, C., Noll, M., Nöckler, K., \& Al Dahouk, S. (2019). Brucella-positive raw milk cheese sold on the inner European market: A public health threat due to illegal import? Food Control, 100(November 2018), 130-137. https://doi.org/10.1016/j.foodcont.2019.01.022

Jofré, A., Latorre-Moratalla, M. L., Garriga, M., \& Bover-Cid, S. (2019). Domestic refrigerator temperatures in Spain: Assessment of its impact on the safety and shelf-life of cooked meat products. Food Research International, 126(July), 108578. https://doi.org/10.1016/j.foodres.2019.108578

Kaczmarek, M., Avery, S. V., \& Singleton, I. (2019). Microbes associated with fresh produce: Sources, types and methods to reduce spoilage and contamination. In Advances in Applied Microbiology (1st ed., Vol. 107). Elsevier Inc. https://doi.org/10.1016/bs.aambs.2019.02.001

Kapetanakou, A. E., Gkerekou, M. A., Vitzilaiou, E. S., \& Skandamis, P. N. (2017). Assessing the capacity of growth, survival, and acid adaptive response of Listeria monocytogenes during storage of various cheeses and subsequent simulated gastric digestion. International Journal of Food Microbiology, 246, 50-63. https://doi.org/10.1016/j.ijfoodmicro.2017.01.015

Kapetanakou, A. E., Makariti, I. P., Nazou, E., Manios, S. G., Karavasilis, K., \& Skandamis, P. N. (2019). Modelling the effect of osmotic adaptation and temperature on the non-thermal inactivation of Salmonella spp. on brioche-type products. International Journal of Food Microbiology, 296(December 2018), 48-57. https://doi.org/10.1016/j.ijfoodmicro.2019.02.010

Lee, R. J., Rangdale, R. E., Croci, L., Hervio-Heath, D., \& Lozach, S. (2008). Bacterial pathogens in seafood. Improving Seafood Products for the Consumer, 158, 247-291. https://doi.org/10.1533/9781845694586.3.247

Letchumanan, V., Loo, K.-Y., Law, J. W.-F., Wong, S. H., Goh, B.-H., Ab Mutalib, N.-S., \& Lee, L.-H. (2019). Progress in Microbes and Molecular Biology Vibrio parahaemolyticus: The Protagonist Causing Foodborne Diseases. Progress In Microbes \& Molecular Biology, 2(1), 1-8.

Li, D., Butot, S., Zuber, S., \& Uyttendaele, M. (2018). Monitoring of foodborne viruses in berries and considerations on the use of RT-PCR methods in surveillance. Food Control, 89, 235-240. https://doi.org/10.1016/j.foodcont.2018.02.024

Lianou, A., Moschonas, G., Nychas, G. J. E., \& Panagou, E. Z. (2018). Growth of Listeria monocytogenes in pasteurized vanilla cream pudding as affected by storage temperature and the presence of cinnamon extract. Food Research International, 106(November 2017), https://doi.org/10.1016/j.foodres.2017.11.027

López-Cuevas, O., Medrano-Félix, J. A., Castro-Del Campo, N., \& Chaidez, C. (2021). Bacteriophage applications for fresh produce food safety. International Journal of Environmental Health Research, 31(6), 687-702. https://doi.org/10.1080/09603123.2019.1680819

López-Gálvez, F., Truchado, P., Tudela, J. A., Gil, M. I., \& Allende, A. (2020). Critical points affecting the microbiological safety of bell peppers washed with peroxyacetic acid in a commercial packinghouse. Food Microbiology, 88(September 2019), 103409. https://doi.org/10.1016/j.fm.2019.103409

Loukiadis, E., Bièche-Terrier, C., Malayrat, C., Ferré, F., Cartier, P., \& Augustin, J. C. (2017). Distribution of Escherichia coli O157:H7 in ground beef: Assessing the clustering intensity for an industrial-scale grinder and a low and localized initial contamination. International Journal of Food Microbiology, 250, 75-81. https://doi.org/10.1016/j.ijfoodmicro.2017.03.009

Lourenco, A., Fraga, M., De Colli, L., Moloney, M., Danaher, M., \& Jordan, K. (2020). Determination of the presence of pathogens and anthelmintic drugs in raw milk and raw milk cheeses from small scale producers in Ireland. Lwt, 130(April), 109347. https://doi.org/10.1016/j.lwt.2020.109347

Lüth, S., Halbedel, S., Rosner, B., Wilking, H., Holzer, A., Roedel, A., Dieckmann, R., Vincze, S., Prager, R., Flieger, A., Al Dahouk, S., \& Kleta, S. (2020). Backtracking and forward checking of human listeriosis 
clusters identified a multiclonal outbreak linked to Listeria monocytogenes in meat products of a single producer. Emerging Microbes and Infections, 9(1), 1600-1608. https://doi.org/10.1080/22221751.2020.1784044

Lytou, A. E., Renieri, C. T., Doulgeraki, A. I., Nychas, G. J. E., \& Panagou, E. Z. (2020). Assessment of the microbiological quality and safety of marinated chicken products from Greek retail outlets. International $\begin{array}{lllll}\text { Journal of Food } & \text { Microbiology, 208506. }\end{array}$ https://doi.org/10.1016/j.ijfoodmicro.2019.108506

Machado-Moreira, B., Richards, K., Brennan, F., Abram, F., \& Burgess, C. M. (2019). Microbial Contamination of Fresh Produce: What, Where, and How? Comprehensive Reviews in Food Science and Food Safety, 18(6), 1727-1750. https://doi.org/10.1111/1541-4337.12487

Madden, R. H., Hutchison, M., Jordan, K., Pennone, V., Gundogdu, O., \& Corcionivoschi, N. (2018). Prevalence and persistence of Listeria monocytogenes in premises and products of small food business operators in Northern Ireland. Food Control, 87, 70-78. https://doi.org/10.1016/j.foodcont.2017.12.020

Marik, C. M., Zuchel, J., Schaffner, D. W., \& Strawn, L. K. (2020). Growth and survival of listeria monocytogenes on intact fruit and vegetable surfaces during postharvest handling: a systematic literature review. Journal of Food Protection, 83(1), 108-128. https://doi.org/10.4315/0362-028X.JFP-19-283

Martinović, T., Andjelković, U., Gajdošik, M. Š., Rešetar, D., \& Josić, D. (2016). Foodborne pathogens and their toxins. Journal of Proteomics, 147, 226-235. https://doi.org/10.1016/j.jprot.2016.04.029

Mataragas, M., Alessandria, V., Ferrocino, I., Rantsiou, K., \& Cocolin, L. (2018). A bioinformatics pipeline integrating predictive metagenomics profiling for the analysis of $16 \mathrm{~S} \mathrm{rDNA} / \mathrm{rRNA}$ sequencing data originated from foods. Food Microbiology, 76(May), 279-286. https://doi.org/10.1016/j.fm.2018.05.009

Mayo, B., Rachid, C., Alegria, A., Leite, A., Peixoto, R., \& Delgado, S. (2014). Impact of Next Generation Sequencing Techniques in Food Microbiology. Current Genomics, 15(4), $293-309$. https://doi.org/10.2174/1389202915666140616233211

Merget, B., Forbes, K. J., Brennan, F., McAteer, S., Shepherd, T., Strachan, N. J., \& Holden, N. J. (2019). Influence of Plant Species, Tissue Type, and Temperature on the Capacity of Shiga-Toxigenic Escherichia coli To Colonize, Grow, and Be Internalized by Plants. Applied and Environmental Microbiology, 85(11), E00123-19., January, 1-16.

Merget, B., Dobrindt, U., Forbes, K. J., Strachan, N. J. C., Brennan, F., \& Holden, N. J. (2020). Variability in growth responses of non-O157 EHEC isolates in leafy vegetables, sprouted seeds and soil extracts occurs at the isolate level. FEMS Microbiology Letters, 367(1), 1-8. https://doi.org/10.1093/femsle/fnaa030

Motawee, M. M., \& Neveen, S. M. (2016). Effect of Starter Culture as a Source of Microbial Contamination on the Quality and Safety of Yogurt in Giza, Egypt. International Journal of Food Science and Nutrition Engineering, 6(5), 103-111. https://doi.org/10.5923/j.food.20160605.01

Nastasijevic, I., Milanov, D., Velebit, B., Djordjevic, V., Swift, C., Painset, A., \& Lakicevic, B. (2017). Tracking of Listeria monocytogenes in meat establishment using Whole Genome Sequencing as a food safety management tool: A proof of concept. International Journal of Food Microbiology, 257(March), 157-164. https://doi.org/10.1016/j.ijfoodmicro.2017.06.015

Ndraha, N., Hsiao, H. I., Vlajic, J., Yang, M. F., \& Lin, H. T. V. (2018). Time-temperature abuse in the food cold chain: Review of issues, challenges, and recommendations. Food Control, 89, 12-21. https://doi.org/10.1016/j.foodcont.2018.01.027

Oliveira, M., Usall, J., Viñas, I., Solsona, C., \& Abadias, M. (2011). Transfer of Listeria innocua from contaminated compost and irrigation water to lettuce leaves. Food Microbiology, 28(3), 590-596. https://doi.org/10.1016/j.fm.2010.11.004

Oliveira, Márcia, Rodrigues, C. M., \& Teixeira, P. (2019). Microbiological quality of raw berries and their products: A focus on foodborne pathogens. Heliyon, 5(12). https://doi.org/10.1016/j.heliyon.2019.e02992

Osimani, A., Cardinali, F., Aquilanti, L., Garofalo, C., Roncolini, A., Milanović, V., Pasquini, M., Tavoletti, S., \& Clementi, F. (2017). Occurrence of transferable antibiotic resistances in commercialized ready-to-eat mealworms (Tenebrio molitor L.). International Journal of Food Microbiology, 263(March), 38-46. https://doi.org/10.1016/j.ijfoodmicro.2017.10.009

Osimani, A., Milanović, V., Garofalo, C., Cardinali, F., Roncolini, A., Sabbatini, R., De Filippis, F., Ercolini, D., Gabucci, C., Petruzzelli, A., Tonucci, F., Clementi, F., \& Aquilanti, L. (2018). Revealing the microbiota of marketed edible insects through PCR-DGGE, metagenomic sequencing and real-time PCR. International Journal of Food Microbiology, 276(March), 54-62. https://doi.org/10.1016/j.ijfoodmicro.2018.04.013

Panghal, A., Chhikara, N., Sindhu, N., \& Jaglan, S. (2018). Role of Food Safety Management Systems in safe food production: A review. Journal of Food Safety, 38(4). https://doi.org/10.1111/jfs.12464

Papadopoulos, P., Angelidis, A. S., Papadopoulos, T., Kotzamanidis, C., Zdragas, A., Papa, A., Filioussis, G., \& Sergelidis, D. (2019). Staphylococcus aureus and methicillin-resistant S. aureus (MRSA) in bulk tank milk, livestock and dairy-farm personnel in north-central and north-eastern Greece: Prevalence, characterization 
and genetic relatedness. Food Microbiology, 84(November 2018). https://doi.org/10.1016/j.fm.2019.103249

Papadopoulou, O. S., Argyri, A. A., Varzakis, E. E., Tassou, C. C., \& Chorianopoulos, N. G. (2018). Greek functional Feta cheese: Enhancing quality and safety using a Lactobacillus plantarum strain with probiotic potential. Food Microbiology, 74, 21-33. https://doi.org/10.1016/j.fm.2018.02.005

Pérez-Rodríguez, F., Kwon, J., Bolívar, A., Sauer, K., Ryu, D., \& Todd, E. (2019). Probabilistic risk model of norovirus transmission during handling and preparation of fresh produce in school foodservice operations. International Journal of Food Microbiology, 290(September 2018), 159-169. https://doi.org/10.1016/j.ijfoodmicro.2018.09.029

Pérez-Rodríguez, F., \& Mercanoglu Taban, B. (2019). A State-of-Art Review on Multi-Drug Resistant Pathogens in Foods of Animal Origin: Risk Factors and Mitigation Strategies. Frontiers in Microbiology, 10(September). https://doi.org/10.3389/fmicb.2019.02091

Peri, C. (2006). The universe of food quality. Food Quality and Preference, 17(1-2), 3-8. https://doi.org/10.1016/j.foodqual.2005.03.002

Petruzzelli, A., Osimani, A., Tavoletti, S., Clementi, F., Vetrano, V., Di Lullo, S., Paolini, F., Foglini, M., Micci, E., Orazietti, N., Luchetti, T., \& Tonucci, F. (2018). Microbiological quality assessment of meals and work surfaces in a school-deferred catering system. International Journal of Hospitality Management, 68(February 2017), 105-114. https://doi.org/10.1016/j.ijhm.2017.10.003

Phiri, B. S. J., Sakumona, M., Hang'ombe, B. M., Fetsch, A., \& Schaarschmidt, S. (2021). The traditional dairy value chain in Zambia and potential risk factors to microbiological food safety. Food Control, 124(January), 107885. https://doi.org/10.1016/j.foodcont.2021.107885

Possas, A., Valdramidis, V., García-Gimeno, R. M., \& Pérez-Rodríguez, F. (2019). High hydrostatic pressure processing of sliced fermented sausages: A quantitative exposure assessment for Listeria monocytogenes. Innovative Food Science and Emerging Technologies, 52(January), 406-419. https://doi.org/10.1016/j.ifset.2019.01.017

Pumipuntu, N., \& Indrawattana, N. (2017). Vibrio parahaemolyticus: a seafood-borne pathogen. J Trop Med Parasitol, 40(2), 50-62.

Rahman, M. S., Carraro, R., Cardazzo, B., Carraro, L., Meneguolo, D. B., Martino, M. E., Andreani, N. A., Bordin, P., Mioni, R., Barco, L., Novelli, E., Balzan, S., \& Fasolato, L. (2017). Molecular Typing of Vibrio parahaemolyticus Strains Isolated from Mollusks in the North Adriatic Sea. Foodborne Pathogens and Disease, 14(8), 454-464. https://doi.org/10.1089/fpd.2016.2263

Rajkovic, A., Smigic, N., Djekic, I., Popovic, D., Tomic, N., Krupezevic, N., Uyttendaele, M., \& Jacxsens, L. (2017). The performance of food safety management systems in the raspberries chain. Food Control, 80, 151-161. https://doi.org/10.1016/j.foodcont.2017.04.048

Ramos, G. L. P. A., Nascimento, J. S., Margalho, L. P., Duarte, M. C. K. H., Esmerino, E. A., Freitas, M. Q., Cruz, A. G., \& Sant'Ana, A. S. (2021). Quantitative microbiological risk assessment in dairy products: Concepts and applications. Trends in Food Science and Technology, 111(March), 610-616. https://doi.org/10.1016/j.tifs.2021.03.017

Rantsiou, K., Kathariou, S., Winkler, A., Skandamis, P., Saint-Cyr, M. J., Rouzeau-Szynalski, K., \& Amézquita, A. (2018). Next generation microbiological risk assessment: opportunities of whole genome sequencing (WGS) for foodborne pathogen surveillance, source tracking and risk assessment. International Journal of Food Microbiology, 287(November 2017), 3-9. https://doi.org/10.1016/j.ijfoodmicro.2017.11.007

Reich, F., Valero, A., Schill, F., Bungenstock, L., \& Klein, G. (2018). Characterisation of Campylobacter contamination in broilers and assessment of microbiological criteria for the pathogen in broiler slaughterhouses. Food Control, 87, 60-69. https://doi.org/10.1016/j.foodcont.2017.12.013

Ripolles-Avila, C., Hascoët, A. S., Ríos-Castillo, A. G., \& Rodríguez-Jerez, J. J. (2019). Hygienic properties exhibited by single-use wood and plastic packaging on the microbial stability for fish. Lwt, 113(December 2018), 108309. https://doi.org/10.1016/j.lwt.2019.108309

Rodríguez-López, P., Rodríguez-Herrera, J. J., \& Cabo, M. L. (2020). Tracking bacteriome variation over time in Listeria monocytogenes-positive foci in food industry. International Journal of Food Microbiology, 315(July 2019), 108439. https://doi.org/10.1016/j.ijfoodmicro.2019.108439

Rohde, A., Hammerl, J. A., Boone, I., Jansen, W., Fohler, S., Klein, G., Dieckmann, R., \& Al Dahouk, S. (2017). Overview of validated alternative methods for the detection of foodborne bacterial pathogens. Trends in Food Science and Technology, 62, 113-118. https://doi.org/10.1016/j.tifs.2017.02.006

Romalde, J. L., Rivadulla, E., Varela, M. F., \& Barja, J. L. (2018). An overview of 20 years of studies on the prevalence of human enteric viruses in shellfish from Galicia, Spain. Journal of Applied Microbiology, 124(4), 943-957. https://doi.org/10.1111/jam.13614

Ronholm, J. (2018). Editorial: Game changer - Next generation sequencing and its impact on food microbiology. Frontiers in Microbiology, 9(MAR), 1-3. https://doi.org/10.3389/fmicb.2018.00363

Rosette, K., Mireille, K., Pierrette, M., Georges, D., Patrick, D. M., \& Mukeng, A. K. (2019). Risk factors 
associated with retail meat vendors in Lubumbashi, Democratic Republic of Congo. African Journal of Food Science, 13(11), 248-260. https://doi.org/10.5897/ajfs2019.1840

Rubini, S., Galletti, G., D’Incau, M., Govoni, G., Boschetti, L., Berardelli, C., Barbieri, S., Merialdi, G., Formaglio, A., Guidi, E., Bergamini, M., Piva, S., Serraino, A., \& Giacometti, F. (2018). Occurrence of Salmonella enterica subsp. enterica in bivalve molluscs and associations with Escherichia coli in molluscs and faecal coliforms in seawater. Food Control, 84, 429-435. https://doi.org/10.1016/j.foodcont.2017.08.035

Russo, P., Spano, G., \& Capozzi, V. (2017). Safety evaluation of starter cultures. Starter Cultures in Food Production, 101-128. https://doi.org/10.1002/9781118933794.ch6

Santarelli, G. A., Migliorati, G., Pomilio, F., Marfoglia, C., Centorame, P., D’Agostino, A., D’Aurelio, R., Scarpone, R., Battistelli, N., Di Simone, F., Aprea, G., \& Iannetti, L. (2018). Assessment of pesticide residues and microbial contamination in raw leafy green vegetables marketed in Italy. Food Control, 85, 350-358. https://doi.org/10.1016/j.foodcont.2017.09.035

Santos, Juliana Lane Paixão dos, Membré, J. M., Jacxsens, L., Samapundo, S., Van Impe, J., Sant'Ana, A. S., \& Devlieghere, F. (2020). Quantitative microbial spoilage risk assessment (QMSRA) of pasteurized strawberry purees by Aspergillus fischeri (teleomorph Neosartorya fischeri). International Journal of Food Microbiology, 333(June), 108781. https://doi.org/10.1016/j.ijfoodmicro.2020.108781

Santos, Juliana Lane Paixão dos, Samapundo, S., Biyikli, A., Van Impe, J., Akkermans, S., Höfte, M., Abatih, E. N., Sant'Ana, A. S., \& Devlieghere, F. (2018). Occurrence, distribution and contamination levels of heatresistant moulds throughout the processing of pasteurized high-acid fruit products. International Journal of Food Microbiology, 281(May), 72-81. https://doi.org/10.1016/j.ijfoodmicro.2018.05.019

Santos, Juliana L.P., Samapundo, S., Gülay, S. M., Van Impe, J., Sant'Ana, A. S., \& Devlieghere, F. (2018). Inter- and intra-species variability in heat resistance and the effect of heat treatment intensity on subsequent growth of Byssochlamys fulva and Byssochlamys nivea. International Journal of Food Microbiology, 279(February), 80-87. https://doi.org/10.1016/j.ijfoodmicro.2018.04.035

Sarno, E., Pezzuto, D., Rossi, M., Lebeana, E., \& Rizzi, V. (2021). A Review of Significant European Foodborne Outbreaks in the Last Decade. Journal of Food Protection, 84(12), 2059-2070. https://doi.org/10.4315/jfp-21-096

Savelli, E., Murmura, F., Liberatore, L., Casolani, N., \& Bravi, L. (2019). Consumer attitude and behaviour towards food quality among the young ones: empirical evidences from a survey. Total Quality Management and Business Excellence, 30(1-2), 169-183. https://doi.org/10.1080/14783363.2017.1300055

Schill, F., Abdulmawjood, A., Klein, G., \& Reich, F. (2017). Prevalence and characterization of extendedspectrum $\beta$-lactamase (ESBL) and AmpC $\beta$-lactamase producing Enterobacteriaceae in fresh pork meat at processing level in Germany. International Journal of Food Microbiology, 257(January), 58-66. https://doi.org/10.1016/j.ijfoodmicro.2017.06.010

Selvaganapathi, R., Jeyasekaran, G., Shakila, R. J., Sukumar, D., Kumar, M. P., \& Sivaraman, B. (2018). Occurrence of Listeria monocytogenes on the seafood contact surfaces of Tuticorin Coast of India. Journal of Food Science and Technology, 55(7), 2808-2812. https://doi.org/10.1007/s13197-018-3230-y

Sharma, M., \& Reynnells, R. (2018). Importance of Soil Amendments: Survival of Bacterial Pathogens in Manure and Compost Used as Organic Fertilizers. Preharvest Food Safety, 1, 159-175. https://doi.org/10.1128/9781555819644.ch9

Sheng, L., Edwards, K., Tsai, H. C., Hanrahan, I., \& Zhu, M. J. (2017). Fate of Listeria monocytogenes on fresh apples under different storage temperatures. Frontiers in Microbiology, 8(JUL), 1-8. https://doi.org/10.3389/fmicb.2017.01396

Smith, A., Moorhouse, E., Monaghan, J., Taylor, C., \& Singleton, I. (2018). Sources and survival of Listeria monocytogenes on fresh, leafy produce. Journal of Applied Microbiology, 125(4), 930-942. https://doi.org/10.1111/jam.14025

Soon, J. M. (2019). Rapid Food Hygiene Inspection Tool (RFHiT) to assess hygiene conformance index (CI) of street food vendors. Lwt, 113(June), 108304. https://doi.org/10.1016/j.lwt.2019.108304

Ssemanda, J. N., Reij, M. W., van Middendorp, G., Bouw, E., van der Plaats, R., Franz, E., Muvunyi, C. M., Bagabe, M. C., Zwietering, M. H., \& Joosten, H. (2018). Foodborne pathogens and their risk exposure factors associated with farm vegetables in Rwanda. Food Control, 89, 86-96. https://doi.org/10.1016/j.foodcont.2017.12.034

Suhendra, A. D., Asworowati, R. D., \& Ismawati, T. (2020). Role of risk analysis and risk communication in food safety management. Akrab Juara, $43-54$. http://www.akrabjuara.com/index.php/akrabjuara/article/view/919

Szczech, M., Kowalska, B., Smolińska, U., Maciorowski, R., Oskiera, M., \& Michalska, A. (2018). Microbial quality of organic and conventional vegetables from Polish farms. International Journal of Food Microbiology, 286(July), 155-161. https://doi.org/10.1016/j.ijfoodmicro.2018.08.018 
Tirloni, E., Nauta, M., Vasconi, M., Di Pietro, V., Bernardi, C., \& Stella, S. (2020). Growth of Listeria monocytogenes in ready-to-eat "shrimp cocktail": Risk assessment and possible preventive interventions. International Journal of Food Microbiology, 108800. https://doi.org/10.1016/j.ijfoodmicro.2020.108800

Truchado, P., Gil, M. I., Suslow, T., \& Allende, A. (2018). Impact of chlorine dioxide disinfection of irrigation water on the epiphytic bacterial community of baby spinach and underlying soil. PLoS ONE, 13(7), 1-17. https://doi.org/10.1371/journal.pone.0199291

Utaaker, K. S., Kumar, A., Joshi, H., Chaudhary, S., \& Robertson, L. J. (2017). Checking the detail in retail: Occurrence of Cryptosporidium and Giardia on vegetables sold across different counters in Chandigarh, India. International Journal of Food Microbiology, 263(June), 1-8. https://doi.org/10.1016/j.ijfoodmicro.2017.09.020

Valero, A., Hernández, M., Esteban-Carbonero, Ó., \& Rodríguez-Lázaro, D. (2018). Modelling the fate and serogroup variability of persistent Listeria monocytogenes strains on grated cheese at different storage temperatures. International Journal of Food Microbiology, 286(July), 48-54. https://doi.org/10.1016/j.ijfoodmicro.2018.07.021

Valero, A., Ortiz, J. C., Fongaro, G., Hernández, M., \& Rodríguez-Lázaro, D. (2017). Definition of sampling procedures for collective-eating establishments based on the distribution of environmental microbiological contamination on food handlers, utensils and surfaces. Food Control, 77(852), 8-16. https://doi.org/10.1016/j.foodcont.2017.01.013

Valero, A., Rodríguez, M.-Y., Posada-Izquierdo, G. D., Pérez-Rodríguez, F., Carrasco, E., \& García-Gimeno, R. M. (2016). Risk Factors Influencing Microbial Contamination in Food Service Centers. Significance, Prevention and Control of Food Related Diseases. https://doi.org/10.5772/63029

Wright, K. M., \& Holden, N. J. (2018). Quantification and colonisation dynamics of Escherichia coli O157:H7 inoculation of microgreens species and plant growth substrates. International Journal of Food Microbiology, 273(December 2017), 1-10. https://doi.org/10.1016/j.ijfoodmicro.2018.02.025

Xylia, P., Botsaris, G., Chrysargyris, A., Skandamis, P., \& Tzortzakis, N. (2019). Variation of microbial load and biochemical activity of ready-to-eat salads in Cyprus as affected by vegetable type, season, and producer. Food Microbiology, 83(May), 200-210. https://doi.org/10.1016/j.fm.2019.05.013

Zampieri, A., Babbucci, M., Carraro, L., Milan, M., Fasolato, L., \& Cardazzo, B. (2021). Combining culturedependent and culture-independent methods: New methodology insight on the Vibrio community of Ruditapes philippinarum. Foods, 10(6). https://doi.org/10.3390/foods10061271

Zampieri, A., Carraro, L., Cardazzo, B., Milan, M., Babbucci, M., Smits, M., Boffo, L., \& Fasolato, L. (2020). Depuration processes affect the Vibrio community in the microbiota of the Manila clam, Ruditapes philippinarum. Environmental Microbiology, 22(10), 4456-4472. https://doi.org/10.1111/1462-2920.15196

Zuber, I., Lakicevic, B., Pietzka, A., Milanov, D., Djordjevic, V., Karabasil, N., Teodorovic, V., Ruppitsch, W., \& Dimitrijevic, M. (2019). Molecular characterization of Listeria monocytogenes isolates from a smallscale meat processor in Montenegro, 2011-2014. Food Microbiology, 79(November 2018), 116-122. https://doi.org/10.1016/j.fm.2018.12.005

Zwirzitz, B., Wetzels, S. U., Dixon, E. D., Stessl, B., Zaiser, A., Rabanser, I., Thalguter, S., Pinior, B., Roch, F. F., Strachan, C., Zanghellini, J., Dzieciol, M., Wagner, M., \& Selberherr, E. (2020). The sources and transmission routes of microbial populations throughout a meat processing facility. Npj Biofilms and Microbiomes, 6(1), 1-12. https://doi.org/10.1038/s41522-020-0136-z 